\title{
Instrumental analysis of volatile (flavour) compounds in milk and dairy products
}

\author{
R Mariaca, JO Bosset * \\ Federal Dairy Research Institute/FAM, CH-3097 Liebefeld-Bern, Switzerland
}

\begin{abstract}
Summary - The present article reviews the most commonly used methods, techniques and equipments for instrumental analysis of volatile (flavour) compounds in milk and dairy products. After listing some previous important review articles, several methods commonly used for sample treatment are described, as well as the following techniques for extraction and concentration prior to gas chromatographic (GC) analysis: static and dynamic headspace, steam distillation, high-vacuum distillation, molecular distillation, direct extraction (liquid/liquid or liquid/solid), supercritical fluid extraction (SFE), simultaneous (steam) distillation extraction (SDE), dialysis, solid-phase extraction (SPE) and solid-phase microextraction (SPME). Two classical injection devices are also described: oncolumn injection and the so-called 'purge and trap' system. The main advantages and disadvantages of current commercially available types of fused silica capillary columns are briefly considered. The newly developed 'chiral' phases are also described. The article reviews some of the numerous detection systems used for qualitative and/or quantitative analyses such as FID or MS detection, FTIR detection, SCD, FPD and NPD detectors used for sulfur- and nitrogen-containing components, AED detection and the 'sniffing device'. Some useful library search systems such as PBM, INCOS $^{\mathrm{TM}}$ and SISCOM (ie, MassLib ${ }^{\circledR}$ ) are mentioned to complete the overview of this topic. Finally, this paper briefly points out some other methods (ie, photometric), capable of determining various specific chemical functions responsible for flavour (carbonyl compounds, etc), as well as promising techniques involving new electronic noses.
\end{abstract}

\section{milk / dairy product / volatile compound / flavour / analytical method}

Résumé - L'analyse instrumentale des composés volatils (de l'arôme) du lait et des produits laitiers. Le présent article passe en revue les méthodes, techniques et équipements les plus utilisés

Oral communication at the IDF Symposium 'Ripening and Quality of Cheeses', Besançon, France, February 26-28, 1996.

* Correspondence and reprints 
pour l'analyse instrumentale des composés volatils (parfois responsables de la flaveur du lait et des produits laitiers). Après avoir cité quelques articles de revue importants, certaines méthodes communément employées pour le traitement des échantillons sont décrites, de même que les techniques permettant l'extraction, la concentration et l'injection des composés de l'arôme en vue de leur chromatographie en phase gazeuse (CPG) : analyse statique et dynamique d'espace de tête ou d'effluves («headspace»), distillation à la vapeur, distillation sous vide poussé, distillation moléculaire, extraction directe liquide/liquide ou liquide/solide, extraction supercritique (SFE), extraction-distillation simultanée (SDE), extraction en phase solide (SPE) et microextraction en phase solide (SPME). Les deux techniques d'injection les plus classiques sont également présentées : l'injection sur colonne et le système appelé «purge and trap» (par entraînement et piègeage). Les principaux avantages et inconvénients des colonnes capillaires modernes en silice fondue sont brièvement cités. Les phases chirales récemment développées sont également décrites. Cet article cite quelques-uns des détecteurs utilisés pour l'analyse qualitative et/ou quantitative des composés de l'arôme : FID, MSD, FTIR, SCD, FPD et NPD (ces trois derniers détecteurs étant utilisés spécifiquement pour l'analyse des composés soufrés et azotés), AED ainsi que la détection par «sniffing». Les systèmes de recherche par bibliothèques de spectres tels que le PBM, INCOS ${ }^{\mathrm{MM}}$ et SISCOM (par exemple, Masslib ${ }^{\circledR}$ ) sont mentionnés. Cet article fait un rappel de quelques autres méthodes (par exemple, photométriques) à même de déterminer des fonctions chimiques responsables de la flaveur (composés carbonylés, par exemple), ainsi que quelques techniques des plus prometteuses incluant les récents nez électroniques.

\section{lait / produit laitier / composé volatil / arôme / méthode d'analyse}

\section{INTRODUCTION}

Our civilisation is characterised by 'hedonism', which partially explains why flavours play an increasing role in human nutrition and why so much research has been carried out on this topic. Involved in the difference between gastronomy and nutrition, flavours have an impact on our senses of smell and taste, whereas food colours have an impact on our vision. Flavours are not really nutrients. They can stimulate our appetite or warn us of a lack of freshness, or of the presence of anti-nutrients, possibly preventing food poisoning.

There has been constant progress over the last 25 years in the development of analytical methods for detecting volatile, odiferous components such as flavours and perfumes. This research has been supported by the food industry on the one hand, and the perfume and cosmetics industry on the other. For the former, the goal has often been to replace labile compounds or to concentrate interesting components, while for the latter, the aim has been to synthetise rare and expensive natural essences. Research on 'off-flavour compounds' in foods has covered all steps from raw materials to final products, including the manufacture, transformation, packaging, transportation and storage of foods.

The development of efficient analytical tools, such as gas chromatography (GC) and related techniques, has greatly contributed to progress in this area. Main accessories include 'on-column' or 'purge and trap' injectors, fused silica capillary columns with stabilised (crosslinked) stationary phases, highly efficient detectors, and fully automatic PC-analysers with software such as MassLib ${ }^{\circledR}$, Systat ${ }^{\circledR}$, Sysgraph ${ }^{\circledR}$, etc for data collection and manipulation.

Some excellent review articles have been published on instrumental and analytical assessment of volatile (flavour) compounds (Day, 
1967; Forss et al, 1967; Schwartz et al, 1968; Wong and Parks, 1968; Forss, 1969, 1971, 1972; Weurman, 1969; Paillard et al, 1970; Teranishi et al, 1971; Adda and Dumont, 1972; Dumont and Adda, 1972; Evans, 1972; Moinas et al, 1973; Ney, 1973; Lacrampe et al, 1975; Jennings and Filsoof, 1977; Bemelmans, 1979; Nursten, 1979; Benkler and Reineccius, 1980; Lamparsky and Klimes, 1981; Maarse and Belz, 1981; Cronin, 1982; Manning and Price, 1983; Jennings and Rapp, 1983; Leahy and Reineccius, 1984; Núñez and Bemelmans, 1984; Reineccius and Anandaraman, 1984; Sugisawa et al, 1984; Schreier and Idstein, 1985; Grosch, 1990; Klein et al, 1990; Vandeweghe and Reineccius, 1990; Careri et al, 1994; Xanthopoulos et al, 1994; Urbach, 1996) as well as a reference book (Marsili, 1996). The aim of this article is to complete and update existing literature on instrumental analysis of volatile (flavour) compounds from milk and dairy products.

\section{PREPARATION AND TREATMENT OF THE SAMPLE, TECHNIQUES OF EXTRACTION, CONCENTRATION AND INJECTION OF THE VOLATILES}

\section{Sample preparation and treatment}

\section{General principles}

Various procedures have been applied to the isolation of volatiles from complex matrices such as milk and dairy products. Since most volatiles are present in both the sample and vapour phase in small amounts or even traces $(<10 \mu \mathrm{g} / \mathrm{kg})$, different steps for the extraction, concentration and injection of volatiles into the GC are required.

Due to the sensitivity of some compounds to heat and/or oxygen, precautions have to be taken during the preparation of the sample and the isolation of the volatiles to ensure that they remain unchanged and to minimise their losses. Moreover, the formation of new compounds (arte- facts) should be prevented. Possible contamination from the atmosphere and laboratory personnel or their activities (eg, by smoking, cosmetics or solvent in the vicinity) must be avoided in trace analytical determinations by working under clean-room conditions.

Only materials and chemicals of high purity must be used. They should always be checked for contamination before use, and if necessary cleaned and purified. Distilled and boiled ultrapure water should be used, especially for 'purge and trap' techniques. Blank test values should be established on a regular basis to ensure the absence of contamination or, if not possible, to subtract the blank from the sample chromatogram.

\section{Homogenisation of solid and semi-solid samples}

Volatile (aroma) compounds in dairy products are generally distributed in a heterogeneous way. Trace analysis requires careful homogenisation of the sample prior to analysis.

A commonly used, convenient and mild technique for cheese is, for example, freezing followed by grating of the sample at low temperature. If necessary, the powder obtained can then be dispersed in water using a high speed homogeniser to obtain representative samples prior to taking an aliquot.

When using headspace techniques, the homogenate obtained will often be adjusted with alkali to $\mathrm{pH} 7.5$ prior to headspace analysis to keep the high concentration of volatile acids dissolved in the aqueous solution as salts. The fraction to be analysed then mainly contains traces of the numerous neutral and alkaline components present (Imhof and Bosset, 1991). Making a homogenate alkaline can destroy some essential components, such as lactones (Urbach et al, 1972).

\section{Separation into acidic, alkaline and neutral fractions}

In general, flavour from dairy products is made up of a large number of volatile compounds 
(Nursten, 1977; Maarse, 1983; Bosset et al, 1995; Molimard and Spinnler, 1996; Urbach, 1996). These may include significant amounts of free carboxylic acids, sulfur compounds, alkaline nitrogen-containing substances such as amines and substituted pyrazines (Nursten and Sheen, 1974) and pyridines and many neutral compounds such as carbonyl compounds (mostly methylketones and aldehydes), primary and secondary alcohols, esters, lactones, ethers, aliphatic and aromatic hydrocarbons (some of them polycyclic: Dafflon et al, 1995), as well as multifunctional components. In consequence, a preliminary separation into acidic, alkaline and neutral fractions can often help if it is included before their instrumental and sensory analysis (Cronin, 1982). Figure 1 highlights a commonly used scheme for such a separation.

\section{Extraction and concentration techniques}

In general, volatile (aroma) compounds are fairly lipophilic. They are consequently dissolved in the original fatty phase or bound to the proteins.
The first step in each procedure consists of their extraction from such a matrix and usually results in a dilute aqueous solution. Prior to GC-analysis, these volatiles must be separated from water and usually concentrated by using an organic solvent or solvent mixture. However, some modern techniques now allow capture of these compounds by direct adsorption onto a solid phase, so avoiding tedious and time-consuming steps.

Numerous techniques have been proposed for the extraction, concentration and injection of volatile food product components, especially of milk products. An update of the methods most frequently used may be summarised as follows:

\section{Headspace techniques}

Regarding headspace techniques, the sample to be analysed is a gas phase aliquot containing volatiles released from the condensed phase. In their classical static form (Görner et al, 1968; Hild, 1979; Kahlhofer, 1981; Price and Manning, 1983; Degorce-Dumas et al, 1986; McNeal and Hollifield, 1990; Ulberth, 1991; Gaafar, 1992; Linssen et al, 1995), these techniques are

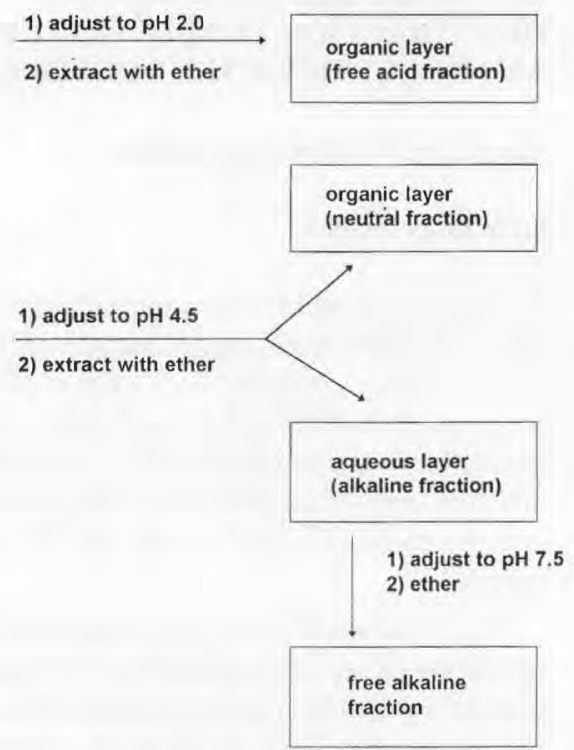

Fig 1. Technique used to isolate the acidic, neutral and alkaline volatile (flavour) compounds. Technique utilisée pour séparer les composés volatils acides, neutres et alcalins (de l'arôme). 
restricted to the most volatile components. The detection of flavour compounds greatly depends on their concentration and vapour pressure, as well as on the temperature and matrix of the food product. A very interesting application is the analysis of volatile acids of cheese, based on esterification in the gas phase prior to analysis (Badertscher et al, 1993). To obtain more concentrated extracts, dynamic headspace methods have been developed (Oria et al, 1987; Urbach, 1987; Horwood, 1989; Imhof and Bosset, 1991; Wijesundera and Urbach, 1993; Contarini and Leardi, 1994; O'Hare and Nursten, 1994; Wood et al, 1994; Yang and Min, 1994), in which the volatile components of the gas phase are continuously removed and concentrated in a cold trap or adsorbed onto an inert support, and finally recovered either by thermal desorption or by elution with a suitable solvent (Westendorf, 1985).

\section{Steam distillation techniques}

Regarding steam distillation techniques, the aqueous distillate is concentrated by liquid/liquid partitioning or by cryoconcentration. Although widely used, these very popular techniques present several problems. For example, highly volatile components may have low recoveries and/or may be masked by the chromatographic peak of the solvent. The solvent may contaminate the sample. In addition, unstable compounds may decompose thermally if the steam distillation and solvent extraction are not carried out under reduced pressure. This technique has been largely applied to cheese varieties such as Emmental (Vámos-Vigyázó and Kiss-Kutz, 1974), Limburger (Parliment et al, 1982), Fontina (Ney and Wirotama, 1978) and Cheddar (Vandeweghe and Reineccius, 1990), as well as to milk (Jeon et al, 1978; Alm, 1982) and other milk products such as butter (Stark et al, 1978), ghee (Jain and Singhal, 1969; Wadhwa et al, 1979), butter oil (Urbach et al, 1972) and milk powder (Ferretti and Flanagan, 1972). Steam distillation has been described recently (Xanthopoulos et al, 1994) as an advantageous method for isolating volatile substances like acetaldehyde, ethanol, diacetyl and acetoin in dairy products.

\section{High-vacuum distillation techniques}

High-vacuum distillation techniques produce small volumes of concentrated aqueous extracts, which are in turn extracted with organic solvents such as methylene chloride and diethyl ether. These techniques prevent thermal degradation by working at ambient or even sub-ambient temperature, but usually require large sample amounts and the operations are very time-consuming. High-vacuum techniques have been applied to solid fat after ultracentrifugation at $25000 \mathrm{~g}$ (McGugan et al, 1968; Manning, 1974) or liquid fat (Liebich et al, 1970) from a homogeneous suspension of fat in water (Bradley and Stine, 1968; Parliment et al, 1982), or even from fat/water/isopentane mixtures (Sloot and Harkes, 1975). Sour cream, as an aqueous suspension, can also be distilled under high vacuum (Mick et al, 1982). Moinas (1973) used a 'gas stripping' technique combined with high vacuum distillation by purging the volatiles with inert gas at low temperatures (Moinas et al, 1973; Groux and Moinas, 1974; Kowalewska et al, 1985). The alkaline volatile components of Swiss Gruyère cheese have been isolated by applying high vacuum gas stripping to grated cheese samples at room temperature, followed by ether extraction of the distillates after they were made alkaline (Liardon et al, 1982). The volatile odorous constituents of different French blue cheeses were isolated by high-vacuum distillation (Gallois and Langlois, 1990). Volatile compounds of different French Appellation d'Origine Contrôlée (AOC) cheeses were extracted by vacuum distillation (Guichard, 1994).

\section{Molecular distillation techniques}

Molecular distillation techniques are very similar to high-vacuum distillation and involve the direct transfer of volatile compounds from the matrix to a cold condenser. These techniques require very short distances between the food sample and condenser, as well as the use of high-vacuum pumping systems $\left(<10^{-3} \mathrm{~Pa}\right)$. Such techniques have 
been used to isolate volatiles from fats and oils, and necessitate water-free samples. Libbey et al (1963) called this 'cold-finger molecular distillation'. Day and Libbey (1964) used this technique to analyse cheese flavour (Cheddar), Stark et al (1976) for butter oil, and Urbach (1982) for milk fat. Dumont et al (1974) described this technique as 'distillation sous vide poussé' (translated as 'high-vacuum distillation'). Molecular distillation has also been carried out by Guichard et al (1987) for Comté cheese, and by Guichard (1995) for Parmigiano, Emmental, Comté and Beaufort cheeses. Volatile compounds from old Cheddar cheese were isolated by molecular distillation (Christensen and Reineccius, 1995).

\section{Direct extraction techniques}

Regarding direct extraction techniques, an extract is obtained by liquid/liquid or liquid/solid partitioning. While these techniques are generally rapid and efficient, they should only be applied to samples with a very low fat content, to keep simultaneous fat extraction low. Because of its low solvent power for triglycerides, acetonitrile can be used to extract cheese flavours. However, the relatively high boiling point of this solvent $\left(82{ }^{\circ} \mathrm{C}\right)$ causes loss of volatile components during the concentration step, Several peaks in the chromatogram will be masked by this solvent (Wong and Parks, 1968; Lamparsky and Klimes, 1981). Preininger et al (1994) treated grated Swiss cheese directly with diethyl ether, filtered off the insoluble material and finally, under high vacuum, distilled the volatile compounds from the non-volatile material (ie, fat), which had dissolved in this solvent. In order to separate the neutral and alkaline fractions from the acidic fraction the distillate obtained, which smelled intensively of Emmentaler cheese, was treated successively with aqueous sodium bicarbonate and aqueous hydrochloric acid (fig I).

\section{Supercritical fluid extraction methods (SFE)}

Supercritical fluid extraction methods (SFE) using carbon dioxide as solvent, avoid the problems of concentrating the extracts. Because of the simul- taneous extraction of mono-, di- and triglycerides and the volatile compounds, the application of these techniques is limited to samples with a low fat content. Currently in the case of cheese samples, SFE-SFC (supercritical fluid chromatography) coupling (Gmür et al, 1987a,b,c) seems to be a possible way of making use of this promising technique; Gmür et al (1986) have already used this on a preparative scale. Commercially available SFE equipment (ie, Hewlett Packard type 7680A/T SFE module or Applied Separations type Spe-de SFE) now allows a release of pressure (after the restrictor) onto a cartridge containing a reverse phase material (similar to that of reverse-phase high performance liquid chromatography, RP-HPLC columns), which can be eluted stepwise by eluents of different polarities. This improvement in SFE systems now permits analysis of trace components in the presence of high amounts of glycerides without any interference or other difficulty.

\section{Simultaneous (steam) distillation extraction methods (SDE)}

Simultaneous (steam) distillation extraction methods (SDE), which were first developed by Nickerson and Likens (1966), use only very lowboiling solvents such as pentane for the concentration of the aroma volatiles. In a continuous process, the condensing water vapour is extracted by the condensing solvent vapour, yielding a high extraction rate. Both the water and the solvent are recirculated. A micro-scale modification, proposed by Godefroot et al (1981), and de Frutos et al (1988) has recently been applied to cheese volatiles. Maignial et al (1992) have proposed a system working under reduced pressure and at low temperature $\left(20-40^{\circ} \mathrm{C}\right)$ to prevent thermal generation of artifacts. Blanch et al (1993) have proposed a micro SDE apparatus working at normal pressure. Careri et al (1994) used this method for the extraction of volatiles in Parmesan cheese.

\section{Dialysis techniques}

Dialysis techniques, which separate volatiles according to their ability to diffuse through a 
membrane, result in a concentration gradient. Although a high degree of concentration was obtained, the sample preparation and dialysis were very time-consuming. This technique was developed by Benkler and Reineccius (1980), modified by Chang and Reineccius (1985), and compared with other techniques by Vandeweghe and Reineccius (1990). A good review on the use of membranes in sample preparation is given by Majors (1995). Application of pervaporation (partial vaporisation through a non-porous permselective membrane) in food processing has been reported by Karlsson and Trägårdh (1996).

\section{Solid-phase extraction methods (SPE)}

Solid-phase extraction methods (SPE) have been used for the selective separation and concentration of analytes from liquid samples. Extraction of the analytes is based on the distribution of dissolved substances (ie, volatiles) between a solid-phase surface and the liquid sample. Separation may be a result of differences in polarity, molecular size, or even differences with respect to ion-exchange capacity. Solid-phase extraction or even micro-solidphase extraction (SPME) techniques (Woolley and Mani, 1994) are relatively new methods for isolating volatiles. Takacs (1989) reported that flavour components in UHT processed milk could be extracted with $\mathrm{C} 18$ Sep-Pak materials and subsequently eluted with methylene chloride. A rapid and sensitive solid phase method was developed by Coulibaly and Jeon (1992) for the extraction of lactones at ppb levels. Analysis of volatiles in various wines using solid phase extraction is described by Sedlácková et al (1995). The use of an on-line SPE-GC-MSD instrument has been recently described by Brinkman and Vreuls (1995).

All aqueous extracts may be concentrated using the freeze-concentration technique, well described by Maarse and Belz (1981), and quoted from the literature by Urbach (1996). Commercial equipment had been proposed (eg, Virtis Co, model 3-100, ser 1049), but less expensive kitchen devices used for domestic ice cream preparation also seem to be convenient for such a purpose.

\section{Injection techniques}

Two types of injection are currently used: oncolumn injection and 'purge and trap' injection. One of the most popular and least expensive pieces of equipment used for many years for loading the volatile (flavour) components of foodstuffs onto a capillary column is the socalled 'cold' injection technique or on-column injection, where the liquid extract is injected directly onto the column. This prevents the loss of substances as well as the discrimination which occurs with the use of a split/splitless injector. Band broadening can be suppressed by stationary phase focussing via a retention gap consisting of a length of uncoated column material (Grob et al, 1985).

The other very common injection technique used is the so-called 'purge and trap' method already mentioned above (see 'dynamic headspace technique'), which is based on the adsorption of compounds onto a trap and/or condensation of the volatiles by low temperature ('cryofocussing') before injection (Imhof and Bosset, 1991).

\section{CHROMATOGRAPHIC SEPARATION, DETECTION, IDENTIFICATION AND QUANTIFICATION}

\section{One-dimensional gas chromatography}

The qualitative and quantitative analyses of complex mixtures of volatile (aroma) components require extremely efficient capillary columns (packed columns are no longer used). The GC separation should be performed exploiting both the volatility and the polarity of the analytes. It must be able to cover a wide spectrum of constituents from non-polar to very polar ones in line with the great variety of the chemical functions present in the mixture. Major progress in this area has been achieved by the introduction of capillary columns based on flexible fused silica tubing material, well known under the abbre- 
viation FSOT (fused silica open tubular columns),

Most capillary columns used today contain a stationary-phase layer that has been cross-linked with the fused silica after coating. Today all traditional high molecular weight phases are available as 'bonded' or 'stabilised stationary phase' under various trade names. These modern crosslinked phases have polarities and separation performances at least comparable to or even better than those of the silicone gum or Carbowaxtype phases they replaced. Capillary columns with internal diameters ranging from $0.10 \mathrm{~mm}$ (small bore) up to $0.53 \mathrm{~mm}$ (wide bore) are commonly used for the analysis of volatile (flavour) compounds.

Polyethyleneglycols (PEG, Carbowax) of various types have been the most popular highly polar phases and the best stationary phases for the separation of food flavour components for more than 25 years (Mick et al, 1982). However, the performance of polydimethylsiloxane as phases with a lower polarity came to be tested recently, especially in dynamic headspace analysis (ie, using 'purge and trap' equipment). These less polar phases prevent the haphazard shifts in retention time observed for some compounds (due to moisture or the high water content of aqueous samples) when PEG-coated capillary columns were used. Moreover, polydimethylsiloxane phases allow use of a much wider temperature range (from -30 up to $300^{\circ} \mathrm{C}$ ) than PEG phases (from +45 up to $250^{\circ} \mathrm{C}$ ) and are less sensitive to oxygen at high temperature (improved longevity).

The best performance for the GC analysis of samples of ripe Swiss Emmental cheese was obtained with a $30 \mathrm{~m} \times 0.32 \mathrm{~mm}$ id capillary column coated with a $4 \mu \mathrm{m}$ layer of $100 \%$ polydimethyl siloxane (SPB-1-SULFUR) (Imhof and Bosset, 1994a). The film thickness of $4 \mu \mathrm{m}$ ensures better resolution and higher loading capacity of the column with samples containing many compounds in different concentrations (fig 2). This column made possible the identification of the highest number of compounds (ie, 58 ) in the cheese sample (table I). Furthermore, highly volatile compounds such as ethanal could be easily detected. Sanz et al (1992) used a mixed-phase (43\% FFAP: polar phase and $57 \%$ OV-1: non polar) and found it to be better for the analysis of volatile fractions from foods.
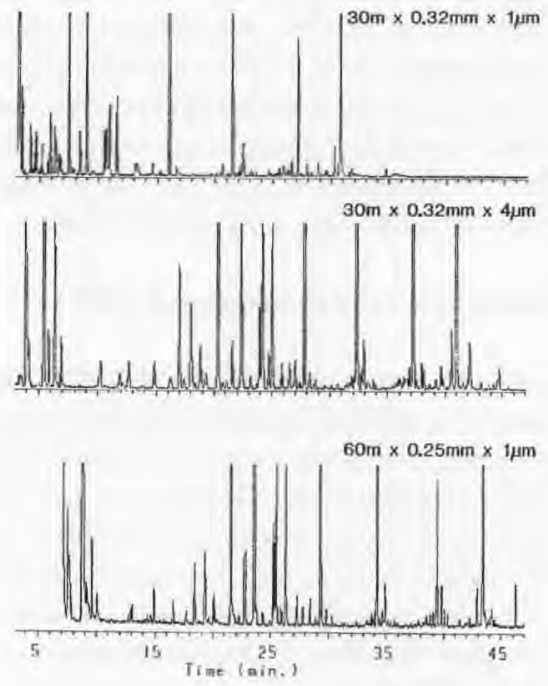

Fig 2. Influence of capillary column dimensions and layer thickness on the chromatograms obtained from a sample of ripe Swiss Emmental cheese using a polydimethylsiloxane stationary phase (SPB-1-SULFUR). The same sample was analysed with the same dynamic headspace method (purge and trap) using identical sample preparation but three different capillary columns. The temperature programme $\left(45^{\circ} \mathrm{C}\right.$ for 13 $\mathrm{min} ; 5^{\circ} \mathrm{C} / \mathrm{min}$ to $220^{\circ} \mathrm{C} ; 220^{\circ} \mathrm{C}$ for $10 \mathrm{~min}$ ) as well as the scale (abundance and retention time) used were identical for the three chromatograms. For further analytical details, see Imhof and Bosset (1994a).

Influence des dimensions de la colonne capillaire et de l'épaisseur du film sur les chromatogrammes d'un échantillon d'emmental suisse affiné, en utilisant une phase stationnaire en polydiméthylsiloxane (SPB-ISULFUR). Le même échantillon a été analysé avec la même méthode (espace de tête dynamique par

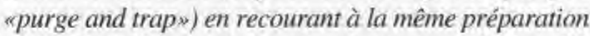
de l'échantillon, mais à trois colonnes capillaires différentes. Le programme de température (13 min à $45^{\circ} \mathrm{C} ; 5^{\circ} \mathrm{C} / \min$ jusqu'à $220^{\circ} \mathrm{C} ; 10 \mathrm{~min}$ à $220^{\circ} \mathrm{C}$ ), de même que les échelles utilisées (abondance et temps de rétention), étaient identiques pour les trois chromatogrammes. Pour d'autres détails analytiques, voir Imhof et Bosset (1994a). 
Table I. Influence of the characteristics of the separation column on the resolution (number of peaks separated*). Influence des caractéristiques de la colonne de séparation sur la résolution (nombre de pics séparés*).

\begin{tabular}{|c|c|c|c|c|c|}
\hline $\begin{array}{l}\text { No of } \\
\text { compounds } \\
\text { identified }\end{array}$ & $\begin{array}{l}\text { Stationary } \\
\text { phase }\end{array}$ & $\begin{array}{l}\text { Dimensions } \\
(m \times m m \times \mu m)\end{array}$ & Polarity & Composition & Supplier \\
\hline 48 & DB-wax & $60 \times 0.25 \times 0.25$ & Polar & $100 \%$ Polyethyleneglycol & $\mathrm{J}+\mathrm{W}$ \\
\hline 33 & Supelco wax & $60 \times 0.32 \times 0.5$ & Polar & $100 \%$ Polyethyleneglycol & Supelco \\
\hline 51 & OV 1701 & $50 \times 0.32 \times 0.5$ & Intermediate & $\begin{array}{ll}88 \% & \text { Methylsiloxane } \\
7 \% & \text { Phenylsiloxane }\end{array}$ & Macherey \& Nagel \\
\hline 51 & Ultra-2 & $50 \times 0.32 \times 0.5$ & Non polar & $\begin{array}{ll}\text { 5\% } & \text { Cyanopropylsiloxane } \\
95 \% & \text { Dimethylpolysiloxane } \\
5 \% & \text { Diphenylnolysiloxane }\end{array}$ & Hewlett-Packard \\
\hline 54 & SE 54 & $50 \times 0.32 \times 0.5$ & Non polar & $\begin{array}{ll}94 \% & \text { Methylsiloxane } \\
5 \% & \text { Phenylsiloxane } \\
1 \% & \text { Vinylsiloxane }\end{array}$ & Macherey \& Nagel \\
\hline 58 & SPB-1** & $30 \times 0.32 \times 4.0$ & Non polar & 100\% Dimethylpolysiloxane & Supelco \\
\hline 47 & SPB-1 & $30 \times 0.32 \times 1.0$ & Non polar & 100\% Dimethylpolysiloxane & Supelco \\
\hline 57 & SPB-1 & $60 \times 0.25 \times 1.0$ & Non polar & 100\% Dimethylpolysiloxane & Supelco \\
\hline
\end{tabular}

* Swiss Emmental cheese sample (Imhof and Bosset, 1994a); ** SPB-1 SULFUR.

* Échantillon d'emmental suisse (Imhof et Bosset, 1994a); ** SPB-1 SULFUR.

Table II lists some chromatographic columns used for the analysis of volatile components in milk and dairy products.

\section{Multidimensional gas chromatography (MDGC)}

The recent development of chiral stationary phases such as cyclodextrins (Bicchi et al, 1992) brought about new highly efficient separation techniques, such as enantioselective multidimensional gas chromatography (MDGC). The use of chiral MDGC in the food industry has dramatically increased in the past few years. It has been applied to identify for example the adulteration of essential oils, fruit juices and many flavoured beverages (Woolley and Mani, 1994). An enantioselective fingerprint can be used to differentiate natural from synthetic raw materials and such a fingerprint is much more difficult to imitate in an adulterated product (Pierce, 1995). The other method described recently by Casabianca et al (1995) deals with the combination of gas chromatography with isotope-ratio mass spectrometry (GC-IRMS). Significant differences were found between the ratio of stable isotopes $\left(\mathrm{eg},{ }^{13} \mathrm{C} /{ }^{12} \mathrm{C},{ }^{2} \mathrm{H} /{ }^{1} \mathrm{H}\right.$ and ${ }^{18} \mathrm{O} /{ }^{16} \mathrm{O}$ ) of natural and synthetic flavours in food products. Scope and limitations of enantioselectivity and isotope discrimination are reported by Mosandl (1995).

\section{Detection systems}

Many detectors have already been proposed for the qualitative and quantitative analysis of volatile (flavour) constituents of foods. Although the following list is not exhaustive, it does indicate those that have been most frequently quoted in the literature: 
Table II. Overview of some separation columns used for the analysis of volatile components of milk and dairy products.

Tableau synoptique de quelques colonnes de séparation utilisées pour l'analyse des composés volatils du lait et des produits laitiers.

\begin{tabular}{|c|c|c|c|c|}
\hline $\begin{array}{l}\text { Stationary } \\
\text { phase }\end{array}$ & $\begin{array}{l}\text { Dimensions } \\
(m \times m m \times \mu m)\end{array}$ & Polarity & $\begin{array}{l}\text { Compounds/product } \\
\text { investigated }\end{array}$ & Ref \\
\hline FFAP & $60 \times 0.3 \times ?$ & Polar & Swiss Gruyère cheese & Liardon et al (1982) \\
\hline DB-5 & $30 \times 0.32 \times 1.0$ & Non polar & Gruyère de Comté & Guichard et al (1987) \\
\hline DB-1 & $30 \times 0.53 \times 1.5$ & Non polar & VOC in milk & McNeal and Hollifield (1990) \\
\hline SE-30 & $22 \times 0.3 \times 0.1$ & Non polar & Artisanal cheese varieties & de Frutos et al (1991) \\
\hline SP 1000 & $25 \times 0.2 \times 0.4$ & Polar & & \\
\hline DB-wax & $60 \times 0.25 \times 0.25$ & Polar & $\begin{array}{l}\text { Parmigiano-Reggiano } \\
\text { Mahon, Comté, Beaufort, } \\
\text { Appenzeller }\end{array}$ & Bosset and Gauch (1993) \\
\hline SE-54 & $30 \times 0.32 \times 0.3$ & Non polar & Key odorants & Preininger et al (1994) \\
\hline OV-1701 & $30 \times 0.32 \times 0.3$ & Intermediate & in Emmentaler cheese & \\
\hline DB-FFAP & ? ? ? & Polar & & \\
\hline DB 1701 & $60 \times 0.32 \times ?$ & Intermediate & AOC cheeses & Guichard (1994) \\
\hline DB-5 & $30 \times 0.25 \times 1.0$ & Non polar & Cheddar cheese & Yang and Min (1994) \\
\hline DB-wax & $30 \times 0.25 \times 0.25$ & Polar & Parmesan cheese & Careri et al (1994) \\
\hline SE-54 & $25 \times 0.32 \times 1.0$ & Non polar & $\begin{array}{l}\text { Flavour defects in milk } \\
\text { powder }\end{array}$ & Ulberth and Roubicek (1995) \\
\hline $\begin{array}{l}\text { DB-wax } \\
\text { (1995) }\end{array}$ & $30 \times 0.25 \times 0.25$ & Polar & Cheddar cheese & Christensen and Reineccius \\
\hline CP Sil 5 CB & $50 \times 0.32 \times 5.0$ & Non polar & Gorgonzola cheese & Contarini and Toppino (1995) \\
\hline
\end{tabular}

?: Not specified in the original publication. VOC: volatile organic compounds; AOC: appellation d'origine contrôlée.

?: Non spécifié dans la publication d'origine ; VOC : composés organiques volatils ; AOC : appellation d'origine contrôlée.

\section{The flame ionisation detector (FID)}

The flame ionisation detector (FID) is certainly the most popular detector used for GC analysis. Its main advantages are its low cost, universal applicability (except for carbon dioxide and formic acid), extremely wide linear range of concentration for quantitative determinations, and long-term stability (the response factors for analytes remain very constant over long periods). As a consequence of its universality, this type of detector is neither specific, nor selective. GC-FID systems have been widely applied to dairy products (Barbieri et al, 1994; Careri et al, 1994; Preininger et al, 1994). Grigoryeva et al (1994) used it for the analysis of Dutch cheese and Monnet et al (1994) to investigate volatile compounds in fermented milk by static headspace techniques. Georgala et al (1995) also used this detector for the assay of flavour compounds in ewe's milk and yoghurt, Ulberth and Roubicek (1995) for detecting flavour defects caused by lipid oxidation, and Contarini and Toppino (1995) for volatile organic compounds (VOC) in Gorgonzola cheese during ripening.

\section{The mass selective detector (MSD)}

The mass selective detector (MSD) is much more expensive than the FID, but it allows both qualitative and quantitative determinations. Two main types are now commercially available: the quadrupole and the ion trap system. Both systems may be used in the full-scan mode (eg, total ion current, TIC) in order to identify compounds via their fragmentation pattern, and in 
the selected ion storage (SIS) or selected ion monitoring (SIM) mode to quantify target compounds with high selectivity and sensitivity. In the scan mode, the identification is mostly performed by comparison with a library of reference spectra (eg, EPA/NIH library, Wiley library, TNO library). In the SIS or SIM mode, the voltages on the ion trap or quadrupole rods are adjusted stepwise to detect only a small number of selected ions (eg, molecular ion, heavy ions, etc) highly specific for the substances to be quantified. Applications of the MSD/SCAN mode to volatile compounds of Emmental cheese have recently been reported by Bosset et al (1995). The MSD/SIM mode was applied for the detection of sulfur-containing compounds in milk after various heat treatments (Bosset et al, 1994, 1996). The GC-MSD technique is the most popular technique used to identify volatile compounds in dairy products: neutral volatile compounds in fresh bovine, ovine, caprine and water buffalo raw milks (Moio et al, 1993a); off-flavour compounds in spray-dried skim milk powder (Shiratsuchi et al, 1994); the volatile components of Cheddar and Swiss cheese (Yang and Min, 1994); the volatile components of fullfat, reduced-fat and low-fat Cheddar cheese (Delahunty et al, 1994); the aroma fraction of Parmesan cheese (Barbieri et al, 1994), and volatile compounds in goat milk cheese (VidalAragón et al, 1994). Dynamic headspace analysis with MS detection was also used by Laye et al (1995) to identify 33 volatile compounds from commercial whey protein concentrate (WPC).

Ion-trap instruments where ionisation and mass analysis both occur in the ion-trap produce nonstandard mass spectra which cannot be compared with commercial data bases. In the latest ion-trap instruments, ionisation and mass analysis have been separated and it is now claimed that these instruments do produce standard spectra.

\section{The Fourier transform infrared spectroscopy (FTIR) detector}

The Fourier transform infrared spectroscopy detection (FTIR) is very expensive and less sen- sitive than the MS detection due to its much higher dead volume and the secondary infrared emission from the heated cell (light-pipe). Similarly to MS, the recorded spectra can be compared with a library of FTIR reference spectra to aid in compound identification, but the commercially available databases are much smaller than those of mass spectra. The FTIR spectra are useful complements to mass spectra, especially for the differentiation of isomers for which MS is not usually helpful (Jackson et al, 1993). Terpenes are an example of substances that may have many isomers due to the position of double bonds. In GC/IR, however, all of these substances show specific absorption bands at different wave numbers (Kasalinsky and McDonald, 1983). The principal capability of the use of high-resolution gas chromatography (HRGC)-FTIR in the analysis of food flavours has been demonstrated by Schreier and Idstein (1985). Industrial applications of GC/FTIR have been described by Namba (1990) with some interesting examples relevant to foods and fragrances.

\section{The flame photometric detector (FPD)}

The flame photometric detector (FPD) is highly selective for sulphur-containing components when a suitable filter is used. Although reliable and sensitive, this detector also suffers from a number of major drawbacks, such as: the well known but unavoidable quenching effects (interferences, eg, from hydrocarbons and carbon monoxide); the non-linear (but sigmoidal) response of the output signal vs the concentration of sulphur species (Burdge and Farwell, 1994).

Prior to the introduction of the SCD (see the following detector), the dominant sulphur-selective detector used in GC was the FPD. This detector configured in parallel with an FID was used by Manning and Moore (1979) to determine hydrogen sulphide and methanethiol by headspace analysis of hard cheeses. Aston and Douglas (1981) described the detection of carbonyl sulphide in Cheddar cheese also using a headspace technique, whereas Parliment et al (1982) examined the VOC of Limburger cheese. 


\section{The sulphur chemiluminescence (SCD) detector}

The sulphur chemiluminescence detector (SCD) is an universal sulphur detector. It has very high sensitivity and selectivity, a linear response to concentration of sulphur species, a large dynamic range, and is free from quenching effects over a wide range. A detailed description of the characteristics of this type of detector is given by Burdge et al (1994). Tuan et al (1995) recently published an interesting evaluation of the performances of FPD, MSD (working in SCAN and SIM mode) and SCD for the determination of sulphur in natural gas. They claimed that the SCD represented the best choice. The detection of sulphur flavour volatiles in cooked milk was reported by Steely (1994). Other applications using static headspace techniques are reported eg, by Nedjma and Maujean (1995) in the analysis of sulphur volatiles in water-alcohol solutions and brandies.

\section{The atomic emission detector (AED)}

The atomic emission detector (AED) is a new detector derived from the well-known atomic emission spectroscopy, used for the analysis of metals and metalloids. It can be tuned to detect any element in any compound that may be eluted by GC. The evaluation of the various detection systems for the determination of volatile sulphur compounds in foods was reviewed by Mistry et al (1994). The study of dynamic range, minimum detectable level and selectivity for a series of sulphur compounds showed that: the upper limit of the linear dynamic range for the AED is six to eight times greater than for the FPD or the SCD (ie, 1200-1550 ng of the compounds injected for the AED vs $200 \mathrm{ng}$ for the FPD and SCD); the minimum detectable level of the sulphur compounds with the AED is as low as $1 \mathrm{pg}$ (vs $200 \mathrm{pg}$ with the SCD and FPD); the selectivity of the AED can be enhanced using the 'snapshot' option. A snapshot is a selected segment of the emission spectrum showing specific elemental emission wavelengths.

\section{The nitrogen phosphorus detector (NPD)}

The nitrogen phosphorus detector (NPD) is highly selective for nitrogen-containing compounds (amines, pyrazines, pyridines, etc). It has similar operating conditions to the FID detector, and is also of low cost. GC-NPD systems have been used in some investigations of flavour components. Nitrogen-containing volatiles of Swiss Gruyère cheese have been determined by Liardon et al (1982). Flavour defects in milk and dairy products due to pyrazines have been reported by Morgan (1976). Lund (1994) also used this detector for the determination of 2-methoxy-3-alkylpyrazines, eg, in carrots.

\section{The 'sniffing device'}

The 'sniffing device' uses the human nose as a detector. It plays a key role as a unique interface with sensory analyses due to its specificity for flavour and off-flavour compounds. Substances are sniffed individually as they are eluted from the GC column. Descriptors may be attributed to each retention time corresponding to an odour-active component (Sävenhed et al, 1985). Quantitative approaches were developed by Acree et al (1984) with the so-called CHARM (combined hedonic aroma response measurement). The analysis is based on sniffing of GC runs of serial dilutions of an odour essence, in order to determine the presence of odour-active zones. The sniffer points out the start and the end of each particular odour perception, and designates it with sensory descriptors. A CHARM value is calculated according to the formula $c=d^{n-1}$ where $n$ represents the number of coincident responses and $d$ the serial dilution factor. Ullrich and Grosch (1987) worked with a similar technique, aroma extract dilution analysis (AEDA), based on the dilution factor (DF), which represents the highest dilution where an odour-active component may still be detected. The resulting values are proportional to the odour number first defined by Rothe and Thomas (1963) as the 'aroma value' (ratio of the concentration of an odour-active compound in the matrix to the detection threshold of this com- 
pound in the same matrix). Miranda-Lopez et al (1992) have developed a quantitative technique called gas chromatography-olfactometry (Osme or $\mathrm{GC}-\mathrm{O}$ ), based on the quantitative measurement of the perceived odour intensity of extracted components after separation on a GC column. Compared to the CHARM or AEDA tests (Etiévant et al, 1994), this method is not based on odour detection thresholds but on odour intensity. Guichard et al (1995) compared this latter technique with both former ones and found similar results. Moio et al (1994) used it for raw, pasteurised and UHT bovine milk. The powerful odorants in bovine, ovine, caprine and water buffalo milk had been previously determined by Moio et al (1993b) using GC-O. Guichard (1994) studied the key flavour compounds in Appellation d'Origine Contrôlée (AOC) cheese by a GC-sniffing technique.

\section{Multiple detection of volatile (aroma) compounds}

Multiple detection of volatile (aroma) compounds has also been proposed by some authors (table III). By using several detectors simultaneously, identification is made more reliable. Detectors may be configured in series or in parallel. Common destructive detectors such as FID, NPD, FPD and MSD must be mounted in parallel, or only as the final detector when configured in series. The FTIR detector, being nondestructive, is coupled in series with MSD in some commercial systems (GC-FTIR-MSD). The software then allows simultaneous recording of the infrared and mass spectra of the eluting compounds. The future in this respect definitely belongs to the spectroscopic detectors that allow selective recognition of the

Table III. Multiple detection of volatile compounds.

Détection multiple des composés volatils.

\begin{tabular}{lll} 
Simultaneous detection & Investigated product & Ref \\
\hline FID/NPD & Nitrogen volatiles in Swiss Gruyère cheese & Liardon et al (1982) \\
Idem & Sulfur volatiles in Limburger cheese & Parliment et al (1982) \\
FID/MSD & VOC in office environment & Mogl et al (1995) \\
Idem & Fatty acid methyl esters & Traitler and Horman (1990) \\
FID/MSD & Sulfur compounds in milk & Bosset et al (1996) \\
FPD/MSD & & \\
FTIR/MSD & Flavour compounds in wine & Buchbauer et al (1994) \\
FID/sniffing & Aroma of aged Cheddar cheese & Christensen and Reineccius \\
Idem & & (1995) \\
MSD/sniffing & Sulfur volatiles in Cucumis melo & Wyllie et al (1994) \\
Idem & Cheddar cheese & Arora et al (1995) \\
FID/SCD/MSD & Blue crab meat volatiles & Flavour compounds in whiskey
\end{tabular}

FID: flame ionisation detector; NPD: nitrogen phosphorous detector; MSD: mass selective detector; FPD: flame photometric detector; FTIR: Fourier transform infrared spectroscopy detector; SCD: sulphur chemiluminescence detector; VOC: volatile organic compounds. 
chromatographed compounds. Today, hyphenated techniques such as GC-MSD, GC-FTIR and $\mathrm{GC}-\mathrm{AED}$ are the most powerful techniques available. Simultaneous detection allows the identification and quantification of almost all aroma compounds present in sufficient amounts after column effluent splitting.

\section{Quantitative analysis}

Two main routes have been described for the quantification of volatile compounds. The first technique is based on spiking the matrix with labelled compounds whose extraction rate and loss during sample treatment, response factor during detection, etc, are equal to those of the (unlabelled) substances to be quantified. Schieberle and Grosch (1987) described this method, called 'isotope dilution assay', for the analysis of aroma compounds. The quantification of a compound in the original matrix is based on the peak height-ratio (or area-ratio) of the unlabelled to the labelled compound (as an internal standard) using the MS detector in the SIM or SIS mode. Thirteen compounds were quantified by this method in Emmentaler cheese (Grosch et al, 1994; Preininger and Grosch, 1994; Preininger et al, 1996).

The second route uses a common standard addition method with increasing quantities of the constituents to be quantified (Imhof and Bosset, 1994b). Thirty-three VOC were quantitatively determined in this way in pasteurised milk and yoghurts in conjunction with dynamic headspace analysis and MS detection.

\section{DATA COLLECTION AND PROCESSING, STATISTICAL ANALYSIS}

Having acquired the mass spectra using electron-impact ionisation (EI), the interpretation of the data stored in the computer can begin. In the full scan mode, the mass spectra contain peak intensities on a mass to charge scale $(\mathrm{m} / \mathrm{z})$. Chromatograms from selected ion recordings (SIM or
SIS mode according to the type of equipment used) and data from multichannel analysers can also be handled. Various sophisticated software packages exist for the manipulation of data, display of spectra and chemical structure plots as well as for peak integration to obtain quantitative information. The main goal is the elucidation of the chemical structure of unknown compounds from their mass spectra. The fastest approach for extracting structural information from spectra is library search combined with the spectroscopist's expertise.

Dedicated software for the coding and searching of the relevant spectra exists in most modern GC-MS systems: a matching procedure compares unknown mass spectra and their intensities $(\mathrm{m} / \mathrm{z}$ values) with those of the reference library. For all useful matches, some matching factors are calculated and a ranked list of the ' $n$ ' best matches ('hit list') is presented, sometimes even as spectra together with their corresponding chemical structures (fig 3).

The following MS libraries are frequently used (nonexhaustive list): commercial libraries of electron-impact ionisation spectra like Wiley with over 275000 spectra, National Institute of Standards and Technology (NIST) with $\approx 63000$ spectra, the Central Institute for Nutrition and Food Research, TNO, Zeist (The Netherlands) library with $\approx 1600$ spectra (especially from food volatiles), and the Chemical Concept (Germany) library with $\approx 35000$ spectra; user libraries of certified spectra; user libraries of unknown or uncertified spectra.

The quality of some of the data contained in some databases is questionable: spectra are often strongly curtailed as to the number of peaks and hence are incomplete, and incorrect spectra taken from old collections may be reincluded in new compilations. Furthermore, threshold spectra frequently miss small but significant peaks.

Among the most powerful search algorithms currently in use, SISCOM (Search for Identical and Similar COMpounds; Damen et al, 1978; Domokos et al, 1983), PBM ( Probability Based Matching System; Pesyna et al, 1976; Atwater et al, 1985) and INCOSTM type searches could be 


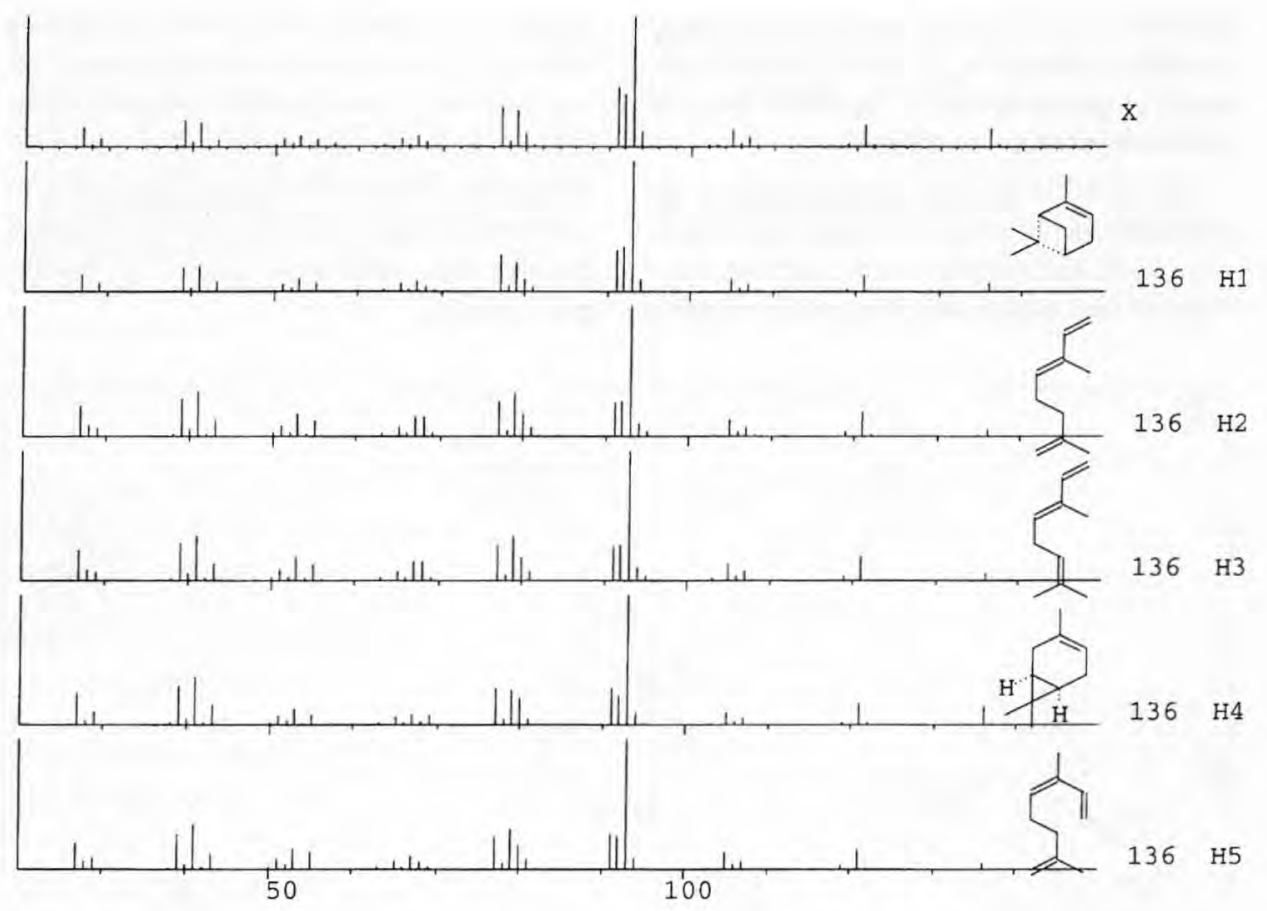

Fig 3. Reference spectra of an unknown compound (x), identified as $\alpha$-pinene $(\mathrm{H} 1)$. The other spectra $(\mathrm{H} 2-\mathrm{H} 5)$ correspond to other structures (best matches) found in different libraries.

Spectres de référence d'un composé inconnu $(x)$ identifié comme étant le $\alpha$-pinène $(H 1)$. Les autres spectres (H2-H5) correspondent aux structures les plus voisines trouvées dans les différentes banques de réference.

mentioned. The SISCOM approach, featuring multiple rankings and also a neutral loss search, often allows the identification of the structural class of compounds, even if no reference spectrum is available. Both spectra and structures may be searched within MassLib ${ }^{\circledR}$, the software featuring SISCOM. It has become possible to identify not only similar spectra, but also to retrieve spectra of similar structures, revealing much of the complex relationship between spectra and structures (Henneberg et al, 1993). The structure search procedure also finds poor quality spectra: this is often a considerable advantage for the expert trying to interpret the spectrum of an unknown compound.

The use of statistics is also helpful for the identification of structural information. Besides structure statistics on 'hit lists', MassLib ${ }^{\circledR}$ offers principal component analysis or PCA (Varmuza et al, 1989). For a group of spectra - for instance the members of a hit list - a number of $n$ spectral features is chosen to represent the spectra as points in an $n$-dimensional feature space. The task is then to investigate the relative position of the objects in this $n$-dimensional space, eg, to find clusters of spectra which lie close together or to determine which spectra are the nearest neighbours of an unknown spectrum. If such clusters of references can be found by the proper selection of features, the position of an object, most often the unknown spectrum, can be used (after a PCA has substantially reduced the number of dimensions) for predictions about the class to which the object belongs. The pointers 
obtained using the various methods finally make possible a stepwise approach to structural elements or partial structures, hopefully even the unknown structure itself (figs 3,4).

MassLib ${ }^{\circledR}$ also offers a second tool for the automatic identification of compounds in routine work: the retention index option. User libraries may additionally contain the retention indices for an apolar, polar and an user-defined column. A calibration file containing index values and their corresponding retention times makes possible the calibration of chromatograms. The two-dimensional approach overcomes the problems associated with substances having very similar mass spectra, eg, for terpenes (fig 5).

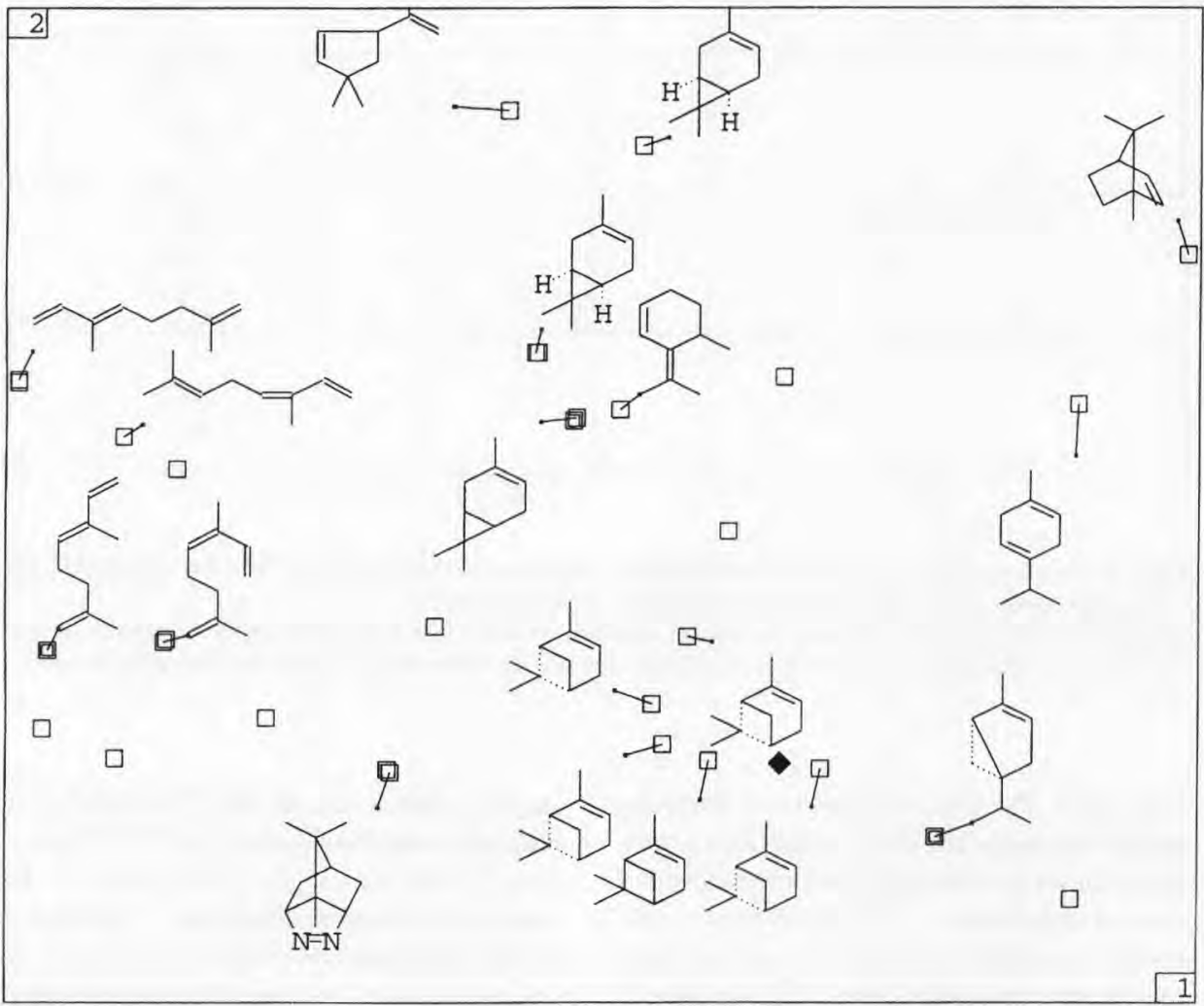

Fig 4. Principal component analysis showing the position of library spectra ( $\square$ ) and thus their relative distances to the unknown ( ). The black lozenge corresponds to the unknown compound. The libraries may contain more than one spectrum of a particular compound. Each square (with or without a line segment) represents a possible chemical structure within a cluster. The distance between the black lozenge and a given square is a measure of the similarity between these structures. For better readability of this figure, only the squares with a line segment show the corresponding chemical structure.

Analyse en composantes principales montrant la position des spectres de masse des banques de référence ( $\square$ ) et leur distance relative au spectre inconnu ( ). Le losange noir correspond au composé inconnu. Les banques de référence peuvent comporter plusieurs spectres d'un composé donné. Chaque carré (segmenté ou non) représente une structure chimique possible à l'intérieur d'un "cluster». La distance entre le losange noir et un carré donné est une mesure de la similitude existant entre ces structures. Pour améliorer la lisibilité de la figure, seuls les carrés segmentés indiquent la structure chimique correspondante. 


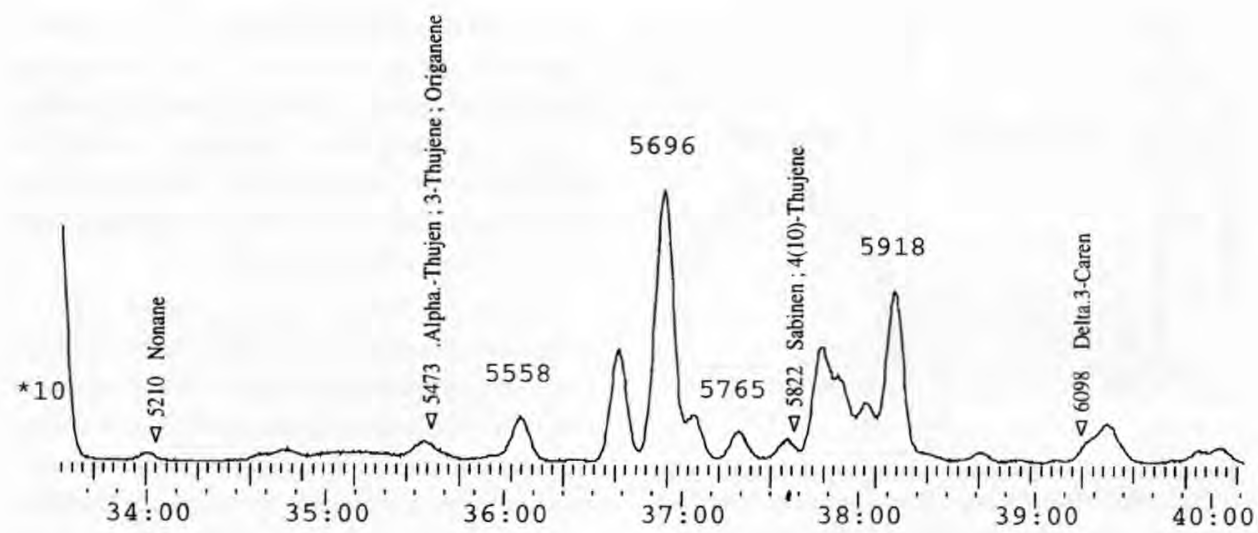

Fig 5. Combined search procedure (total ion current, TIC, and retention index) to identify terpenes. The presence of several possible names for a given mass spectrum and a given retention index indicates that it could be useful to use another stationary phase to identify the unknown compound (abscissa: retention time, min).

Procédure de recherche combinée (courant ionique total et indice de rétention) pour l'identification de terpènes. L'existence de plusieurs noms possibles pour un spectre de masse et un indice de rétention donnés indique qu'il pourrait être utile de recourir à d'autres phases stationnaires pour identifier le composé inconnu (abscisse: temps de rétention, $\mathrm{min}$ ).

\section{ELECTRONIC OR ARTIFICIAL NOSES}

The idea of an instrument for the analysis of volatile (aroma) compounds that mimics the human nose is not new. The goal has been to obtain a relatively quick response, as comparable as possible to that of the human nose. However, technological improvements have only recently provided 'sniffing' devices called 'electronic' or 'artificial' noses which claim to satisfy such requirements.

The principle of the functioning of such a nose is claimed to be similar to that of the human nose: several reactions take place between one or more volatile (flavour) components and an array of sensors (from four up to 32 according to the type of electronic nose). Their relatively rapid reaction involves the adsorption/desorption of volatiles on the surface of the sensors. These reactions are measured, and their results are expressed numerically. With the help of dedicated software, the numbers are then submitted to data analysis or signal processing and presented graphically.
Several types of gas sensors can be used for this task. Because of the specificity, selectivity and sensitivity of these sensors (more than 60 different polymers are available today), a final pattern ('fingerprint') of the sample can be obtained. The main types of sensors which have been developed for such analyses are the following:

- conducting organic polymers, such as polypyrrole and polyaniline, working at relatively low temperatures (usually $<80^{\circ} \mathrm{C}$ ). They require very little energy power. It is possible to prepare polymers which are highly specific for particular classes of volatiles;

- semiconductors such as metal oxides $\left(\mathrm{SnO}_{2}\right.$, $\mathrm{ZnO}, \mathrm{WO}_{3}$ ) working at high temperatures (up to $650^{\circ} \mathrm{C}$ ), which avoids interference from water and improves the response and regeneration time. In both cases, it is possible to measure the change in the electrical resistance (or conductance) during the reactions (fig 6) of the sensors with the volatile substances (Zannoni, 1995); 


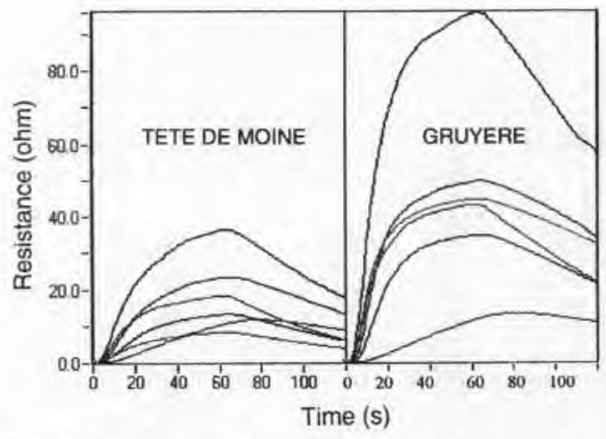

Fig 6. Change in resistance using an electronic nose (FOX 3000, Alpha MOS) with 12 sensors by analysing vapours (volatiles) of Tête de Moine and Swiss Gruyère cheese. The vapours are injected over the 12sensor array for $60 \mathrm{~s}$ before switching off the automatic injection valve. The response of six sensors is plotted: absorption for $60 \mathrm{~s}$, desorption for $60 \mathrm{~s}$. Variation de la résistance d'un nez électronique (FOX 3000, Alpha MOS) à 12 capteurs lors de l'analyse des effluves de fromages de type Tête de Moine et Gruyère suisse. Les effluves sont injectées dans un réseau de 12 capteurs pendant 60 s avant la fermeture automatique de la valve d'injection. La réponse de six capteurs est représentée graphiquement : $60 \mathrm{~s}$ d'adsorption, $60 \mathrm{~s}$ de désorption.

- quartz resonators, which consist of a piezoelectric quartz oscillator coated with a sensing membrane. The adsorption of volatile (flavour) components results in a mass change that can be measured as a shift of the initial frequency (Zannoni, 1995);

- surface acoustic wave (SAW), amperometric and metal oxide semiconductor field effect transistor (MOSFET) devices can also be used as gas sensors for this purpose (Zannoni, 1995).

With conducting organic polymers, the change in conductance can be caused by two different mechanisms: direct interaction between the gas phase molecules (volatiles) and the polarons, which have $n$ cationic sites, and bipolarons with $2 n$ cationic sites in the polymer; interaction between the vapour molecules and the anionic counterions (primary dopants) and solvent matrix.
It is likely that both processes occur simultaneously in the polymer. The interaction between the analyte and the polymer (secondary doping) is rapid and reversible. The analyte molecules only interact with the surface layers of the polymer, which explains the relatively short recovery time after an exposure,

In porous metal oxide sensors (MOS), chemisorbed oxygen irreversibly oxidises volatile (flavour) compounds, a process which produces one or more conducting electrons. The free electrons tend to reduce the potential barrier between oxide grains, increasing the electron mobility and overall electrical conductivity of the material. This reaction depends on various physical and chemical parameters such as the microstructure of the sensor film and the operating temperature of the oxide (typically $250-650^{\circ} \mathrm{C}$ ). The material shows a sensitivity at the sub-ppm level for reducing combustible gases (Pearce et al, 1993; Tan et al, 1995). The mechanism can be summarised by the following reaction: $[\mathrm{R}]+\left[\mathrm{O}^{-}\right]$ $\rightarrow[\mathrm{RO}]+\left[\mathrm{e}^{-}\right]$(Tan et al, 1995).

After data generation and collection, the final stage of data processing uses pattern recognition algorithms, such as discriminant functions, $\mathrm{K}$-nearest neighbour, template matching, cluster analysis, and partial least squares, in an artificial neural network (ANN) to distinguish between similar volatiles. The system is selftraining; the more data are presented, the more discriminating the system becomes. These data sets are processed in a manner similar to that of the brain. The ANN's processing elements, or nodes, are akin to the neurones in the brain. Learning is accomplished by varying the emphasis placed on the output of one sensor in relation to another. It is derived from the mathematical or 'Euclidean' distance between data sets. Pattern recognition involves training and prediction. In the training phase, patterns from the measurements of standard reference samples are used to develop mathematical rules for assigning them to their respective classes (fig 7). In the prediction phase, the rules evolved are applied to assign unknown data sets to respective classes. 


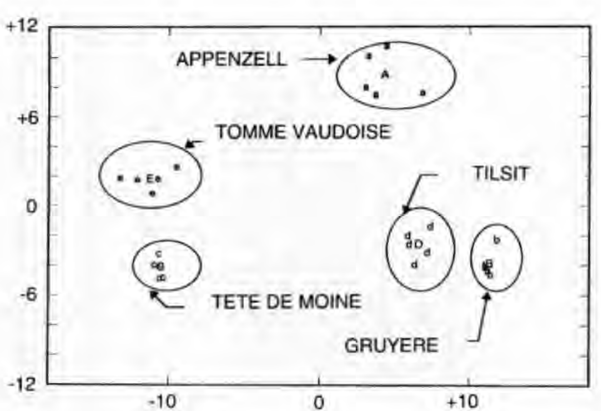

Fig 7. Clusters obtained by discriminant factorial analysis of five Swiss cheese varieties by using a 12-sensor electronic nose (FOX 3000, Alpha MOS), Refer to figure 6 for operating conditions.

Clusters obtenus par analyse factorielle discriminante de cinq sortes de fromages suisses en utilisant un «nez électronique» à 12 capteurs (FOX 3000, Alpha MOS). Voir figure 6 pour les conditions opératoires.

\section{OTHER INSTRUMENTAL METHODS}

In addition to the methods already described in this article for qualitative and quantitative analysis of volatile (flavour) compounds, photometry should be also mentioned. This technique may be applied to some classes of compounds bearing certain functional groups, such as carbonyls, carboxyls and alcohols, which can be derivatised by introducing specific chromophores with absorption in the UV or visible region (Imhof and Bosset, 1989). These methods have been used especially for quantifying carbonyl compounds (methyl ketones and aldehydes) with reagents such as 2,4 dinitrophenylhydrazine (DNPH) to form the corresponding coloured phenylhydrazones. Today, however, photometric methods are less frequently used, modern GC methods being much more sensitive, specific, reproducible and therefore very trustworthy. The former methods, however, can be useful in the exploratory stages and again later as confirmatory tests. Furthermore, photometric methods require frequent calibration and the elimination of background noise using a blank. In addition, the absorption bands used correspond more to chemical 'functions' (monocar- bonyl, ketoglycerides, etc) than to particular substances. As a result, the photometrically determined absorbance corresponds to the absorbance of a mixture of compounds, even though each component has in fact its own specific molecular absorbance.

Several other methods have also been proposed for the analysis of volatile (flavour) compounds, such as high pressure liquid chromatography (HPLC) (Kubeczka, 1981; Dafflon et al, 1995), or NMR (Formácek and Kubeczka, 1982) which cannot be treated in the present article as they would be out of context.

\section{CONCLUSION}

This review updates the possibilities and limitations of modern instrumental analysis of volatile (flavour) compounds in milk and dairy products and describes some of the difficulties encountered in carrying it out. The harder it is to overcome an analytical challenge, the more creative the solution must be.

In general, GC is the method universally applied with the help of several highly efficient modes of extraction, (pre)concentration, injection, separation, and qualitative or quantitative detection of the volatile (flavour) compounds. All these techniques, however, have a common major drawback: the volatiles analysed are not entrapped or embedded in their original matrix, but have been converted into an extract. Consequently, they are present at concentrations that diverge greatly from those in the original food sample. Furthermore, the rheological properties of the matrix itself, which play a key role in flavour perception, are completely lost by this strategy.

In spite of the remarkable progress and development in this field, there is no ideal universal method for the simultaneous analysis of all volatile (flavour) compounds. Each method briefly described in this review presents both advantages and disadvantages (eg, table IV). This probably explains the numerous methods currently available. They may be easy and time- 
Table IV. Summary of some main advantages and disadvantages of four techniques used in the authors' laboratory for the extraction and concentration of volatile (flavour) compounds from milk and dairy products as well as for their injection into a GC.

Résumé des principaux avantages et inconvénients de quatre techniques utilisées par les auteurs pour l'extraction et la concentration des composés volatils (de l'arôme) du lait et des produits laitiers et pour leur injection dans un GC.

Method

High vacuum and low-temperature distillation

$$
\begin{gathered}
2500 \\
3 \text { days } \\
0-10 \\
0.001
\end{gathered}
$$

Temperature $\left({ }^{\circ} \mathrm{C}\right.$

Pressure (mbar)

Application

Research

Advantages

Mild extraction
Concentrated extracts

Multiple injections possible

Distillate can be used

for other analyses

Large amount of sample a

Time and labspace consuming

Multiple processing steps

High vacuum

Organic solvent ${ }^{b}$

Loss in concentration step

Artefacts and impurities

(eg, joint grease) $c$

Suitable only for solid samples
Dynamic headspace analysis (Rektorik equipment)
Dynamic headspace analysis (Tekmar equipment)
$5-25$

$1.5 \mathrm{~h}$

40

Research/routine

Research/routine

Suitable for components of medium to low volatility

Multiple injections possible

Distillate can be used

for other analyses

Internal standard possible

Multiple processing steps

Breakdown reactions of

thermolabile components

Organic solvent ${ }^{b}$

Loss in concentration step

Artifacts and impurities

(eg, joint grease)
$2 \mathrm{~h}$

40

Ambient

Research/routine

Small amount of sample

No organic solvent needed

Extraction and concentration

in one step

Internal standard possible

Foam problems with

liquid samples

Multiple injection not possible

Only two adsorbent materials

available: graphite and charcoal

Desorption temperature not measurable

Production of artifacts

in desorption step
As for Rektorik and additionally:

Suitable for components of high

and medium volatility

Several adsorbents available

Foam problems with

liquid samples

Multiple injection not possible

Purity of water

Purity of purge gas

Cooling with liquid nitrogen

Not possible to use split injection

${ }^{a}$ Much smaller samples down to $10 \mathrm{~g}$ or even less can be used. ${ }^{b}$ Aqueous distillates can be concentrated and injected directly into the GC. Liquid fat or even aqueous solutions can be used provided the water is first distilled off. ${ }^{c}$ Joint grease can be replaced by Teflon sleeves.

${ }^{a}$ Des quantités d'échantillons plus petites que $10 \mathrm{~g}$ peuvent être utilisées. ${ }^{b}$ Les distillats aqueux peuvent être concentrés et injectés dans un GC. La graisse liquide et même des solutions aqueuses peuvent être utilisées, à condition d'éliminer l'eau auparavant. ${ }^{c}$ La graisse pour haut vide peut être remplacée par des manchettes en téflon. 
saving, or complicated and tedious. Some of them are specific for certain compounds, and suitable for routine assays, while others are more appropriate for research. The numerous methods and techniques proposed are complementary, but no one in particular seems to predominate today.

The other instrumental approach recently proposed is the so-called 'electronic' or 'artificial' nose, which allows one to investigate volatile (flavour) compounds directly in their original food matrix. Consequently, the electronic nose represents real progress. Such an analysis is very rapid compared to, for example, a GC analysis with its series of steps. However, in the perception of volatile flavours, an electronic nose, equipped with $4,5,6,12,18$ or 32 sensors, cannot compete with the thousands of sensitive nerve endings active in the human nose and retronasal system.

Finally, in both strategies, ie, the sequential approach (GC analysis) and the direct global approach (assays with an electronic nose), highly efficient software is essential for the statistical treatment of data such as univariate and multivariate analyses.

To conclude, on the one hand, even the most efficient hardware and software currently available cannot compare with the extraordinary capacities of the human brain to analyse flavour stimuli with the help of memory in a context of long-term cultural and social education. On the other hand, it is well known that odour-detecting capacities vary greatly among individuals. The result of smelling can be influenced by the sniffing technique, the type of odorant mixtures, the adaptation to the environment, and the age and the psychophysical conditions of the subject. Many volatile molecules are barely detectable by the human nose. In addition, the response of our senses are difficult to quantify, even when using standard calibration procedures. For all these reasons, sensory analysis can be much more difficult and costly to apply in comparison with instrumental analysis, but, as far as flavour is concerned, the human nose is found to be the ultimate arbiter.

\section{ACKNOWLEDGMENTS}

The authors are grateful to T Berger (FAM, Liebefeld-Bern, Switzerland), F Friedli (MSP Friedli \& Co, Köniz, Switzerland), S Gregory (Sensory Science, NZ Dairy Research Institute, Palmerston North, New Zealand), L Hunt (Palatine, IL, 60067, USA), H Nursten (Dept Food Sci Technol, University of Reading, Reading, UK), V Raverdino (Hewlett-Packard SA, Meyrin, Switzerland), N Skinner (Centre suisse d'électronique et de microtechnique, Neuchâtel, Switzerland), G Urbach and C Wijesundera (CSIRO Div, Food Sci Technol, Melbourne Laboratory, Highett, VIC, Australia) for careful reviewing of this article and valuable linguistic assistance, as well as to R Gauch (FAM, Liebefeld-Bern, Switzerland) for technical assistance.

\section{REFERENCES}

Acree TE, Barnard J, Cunningham DG (1984) A procedure for the sensory analysis of gas chromatographic effluents. Food Chem 14, 273-286

Adda J, Dumont JP (1972) Etude des différentes méthodes d'extraction d'arôme de fromage. Ind Aliment Agric 89, 143-145

Alm L (1982) Effect of fermentation on volatile acids and ethanol in Swedish dairy products. $J$ Dairy Sci $65,186-190$

Arora G, Cormier F, Lee B (1995) Analysis of odoractive volatiles in Cheddar cheese headspace by multidimensional GC/MS/sniffing. J Agric Food Chem 43, 748-752

Aston JW, Douglas K (1981) Detection of carbonyl sulphide in Cheddar cheese headspace. I Dairy Res 48, 473-478

Atwater BL, Stauffer DB, McLafferty FW, Peterson DW (1985) Reliability ranking and scaling improvements to the probability based matching system for unknown mass spectra. Anal Chem 57, 899-903

Badertscher R, Liniger A, Steiger G (1993) Bestimmung der flüchtigen Fettsäuren in Käse aus dem Wasserdampfdestillat mit 'Headspace-GC/FID'. FAM-Info, June 1993, 272w, 1-9

Barbieri G, Bolzoni L, Careri M, Mangia A, Parolari G, Spagnoli S, Virgili R (1994) Study of the 
volatile fraction of Parmesan cheese. J Agric Food Chem 42, 1170-1176

Bemelmans JMH (1979) Review of isolation and concentration techniques, In: Progress in Flavour Research (Land DG, Nursten HE, eds) Appl Sci Publ, London, 79-98

Benkler KF, Reineccius GA (1980) Flavor isolation from fatty foods via solvent extraction and membrane dialysis. J Food Sci 45, 1084-1085

Bicchi C, Artuffo G, D'Amato A, Galli A, Galli M (1992) Cyclodextrin derivatives in the GC separation of racemic mixtures of volatile compounds. Part IV. J High Resol Chromatogr 15, 655-658

Blanch GP, Tabera J, Herraiz M, Reglero G (1993) Preconcentration of volatile components of foods: optimization of the steam distillation-solvent extraction at normal pressure. J Chromatogr 628 . 261-268

Bosset JO, Gauch R (1993) Comparison of the volatile flavour compounds of six European 'AOC' cheeses by using a new dynamic headspace GC-MS method. Int Dairy J 3, 359-377

Bosset JO, Bühler-Moor U, Eberhard P, Gauch R, Lavanchy P, Sieber R (1994) Dimethylsulfid- und Dimethyldisulfidgehalt sowie Aroma als Indikatoren für die thermische Behandlung von Milch. Schweiz Milchwirtsch Forsch 23, 67-71

Bosset JO, Gauch R, Mariaca R, Klein B (1995) Comparison of various sample treatments for the analysis of volatile compounds by GC-MS: application to the Swiss Emmental cheese. Mitt Geb Lebensmittelunters Hyg 86, 672-698

Bosset JO, Eberhard P, Gallmann P, Gauch R, Rattray W, Sieber R (1996) Occurrence and behaviour of volatile sulfur-containing compounds in milk by heat treatment. In: Heat Treatments and Alternative Methods. Proc IDF Symp, Vienna, Austria, 6-8 Sept 1995, 409-421

Bradley RL Jr, Stine CM (1968) A gas chromatographic study of the volatile flavors in natural and spray-dried Cheddar cheese. $J$ Gas Chromatogr $6,344-348$

Brinkman UAT, Vreuls RJJ (1995) Solid-phase extraction for on-line sample treatment in capillary gas chromatography, LC-GC Int 8, 694-698

Buchbauer G, Jirovetz L, Wasicky M, Herlitschka A, Nikiforov A (1994) Aroma von Weissweinblüten: Korrelation sensorischer Daten mit HeadspaceInhaltstoffen. Z Lebensm Unters Forsch 199, 1-4

Burdge JR, Farwell SO (1994) Comparison of combustion sources for sulfur chemiluminescence detection. J High Resol Chromatogr 17, 22-24
Burdge JR, Cai Z, Papillon J, Farwell S (1994) A novel focusing injection technique for chemiluminescent detection of volatile sulfur compounds separated by HRGC. J High Resol Chromatogr 17. 695-699

Careri M, Manini P, Spagnoli S, Barbieri G, Bolzoni L (1994) Simultaneous distillation-extraction and dynamic headspace methods in the gas chromatographic analysis of Parmesan cheese volatiles. Chromatographia 38, 386-394

Casabianca H, Graff JB, Jame P, Perrucchietti C (1995) Application of hyphenated techniques to the chromatographic authentication of flavors in food products and perfumes. J High Resol Chromatogr 18, 279-285

Chang YI, Reineccius GA (1985) Isolation of flavor compounds in model systems by countercurrent continuous dialysis. I Agric Food Chem 33 , 1168-1173

Christensen KR, Reineccius GA (1995) Aroma extract dilution analysis of aged Cheddar cheese. I Food Sci $60,218-220$

Chung HY, Cadwallader KR (1994) Aroma extract dilution analysis of blue crab meat volatiles. J Agric Food Chem 42, 2867-2870

Contarini G, Leardi R (1994) Use of experimental design to optimize the analysis of volatile compounds by dynamic headspace extraction followed by cold trapping and capillary GC. I High Resol Chromatogr 17, 91-94

Contarini G, Toppino PM (1995) Lipolysis in Gorgonzola cheese during ripening. Int Dairy J 5 , 141-155

Coulibaly K, Jeon UJ (1992) Solid-phase extraction of less volatile flavor compounds from ultra-high temperature processed milk. J Agric Food Chem 40, 612-616

Cronin DA (1982) Techniques of analysis of flavours. In: Food Flavours. Part A. Introduction (Morton ID, MacLeod AJ, eds) Elsevier, Amsterdam, 15-48

Dafflon O, Gobet H, Koch H, Bosset JO (1995) Le dosage des hydrocarbures aromatiques polycycliques dans le poisson, les produits carnés et le fromage par chromatographie liquide à haute performance. Trav Chim Aliment Hyg 86, 534-555

Damen H, Henneberg D, Weimann B (1978) Siscom - a new library search system for mass spectra. Anal Chim Acta 103, 289-302

Day EA (1967) Cheese flavor. In: Symposium on Foods: The Chemistry and Physiology of Flavors (Schultz HW, Day EA, Libbey LM, eds) Avi Publ, Westport, CT, 331-361 
Day EA, Libbey LM (1964) Cheddar cheese flavor: gas chromatographic mass spectral analyses of the neutral components of the aroma fraction. J Food Sci 29, 583-589

de Frutos M, Sanz J, Martinez-Castro I (1988) Simultaneous distillation-extraction (SDE) method in the qualitative and quantitative GC analysis of cheese volatile components. Chromatographia 25 , $861-864$

de Frutos M, Sanz J, Martinez-Castro I (1991) Characterization of artisanal cheeses by GC and GC/MS analysis of their medium volatility (SDE) fraction. J Agric Food Chem 39, 524-530

Degorce-Dumas R, Goursaud J, Leveau JY (1986) Analyse de composés volatils du yaourt par chromatographie en phase gazeuse-espace de tête (headspace). Ind Aliment Agric 103, 805-808

Delahunty CM, Piggott JR, Conner JM, Paterson A (1994) Low-fat Cheddar cheese flavour: flavour release in the mouth. In: Trends in Flavour Research. (Maarse H, van der Heij DG, eds) Elsevier, Amsterdam, 47-52

Domokos L, Henneberg D, Weimann B (1983) Optimization of search algorithms for a mass spectra library. Anal Chim Acta 150, 37-44

Dumont JP, Adda J (1972) Isolement des constituants de l'arôme des fromages : comparaison de méthodes, Lait 52, 311-323

Dumont JP, Roger S, Adda J (1974) Composés volatils du fromage entier et du fromage râpé : exemple du Parmesan. Lait 54, 386-396

Etiévant PX, Moio L, Guichard E, Langlois D, Leschaeve I, Schlich P, Chambellant E (1994) Aroma extract dilution analysis (AEDA) and the representativeness of the odour of food extracts. In: Trends in Flavour Research (Maarse H, van der Heij DG, eds) Elsevier, Amsterdam, 179-190

Evans EW (1972) Instrumental and analytical assessment of flavour. J Soc Dairy Technol 25, 125-135

Ferretti A, Flanagan VP (1972) Steam volatile constituents of stale nonfat dry milk. The role of the Maillard reaction in staling. $J$ Agric Food Chem 20, 695-698

Formácek V, Kubeczka KH (1982) Essential Oils Analysis by Capillary Gas Chromatography and Carbon-13NMR Spectroscopy. John Wiley and Sons, Bristol

Forss DA (1969) Flavors of dairy products: a review of recent advances. J Dairy Sci 52, 832-840

Forss DA (1971) The flavors of dairy fats - a review. I Am Oil Chem Soc 48, 702-710
Forss DA (1972) Odor and flavor compounds from lipids. In: Progress in the Chemistry of Fats and Other Lipids, val XIII, part 4 (Holman RT, ed) Pergamon Press, Oxford, 177-258

Forss DA, Jacobsen VM, Ramshaw EH (1967) Concentration of volatile compounds from dilute aqueous solutions. J Agric Food Chem 15, 1104-1107

Gaafar AM (1992) Volatile flavour compounds of yoghurt. Int J Food Sci Technol 27, 87-91

Gallois A, Langlois D (1990) New results in the volatile odorous compounds of French cheeses. Lait 70, 89-106

Georgala AIK, Tsakalidou E, Kandarakis I, Kalantzopoulos G (1995) Flavour production in ewe's milk and ewe's milk yoghurt, by single strains and combinations of Streptococcus thermophilus and Lactobacillus delbrueckii subsp bulgaricus, isolated from traditional Greek yoghurt. Lait 75 , 271-283

Gmür W, Bosset JO, Plattner E (1986) Löslichkeit von einigen Käseinhaltsstoffen in überkritischem Kohlendioxid. Lebensm Wiss Technol 19, 419-425

Gmür W, Bosset JO, Plattner E (1987a) Beitrag zur direkten Kopplung Fluidextraktion-Kapillarfluidchromatographie, I. Theoretische Optimierung einiger wichtiger apparativer Parameter. I Chromatogr 388, 143-150

Gmür W, Bosset JO, Plattner E (1987b) Beitrag zur direkten Kopplung Fluidextraktion-Kapillarfluidchromatographie, II. Aufbau eines Prototyps und Anwendungsbeispiele. I Chromatogr 388 , 335-349

Gmür W, Bosset JO, Plattner E (1987c) Beitrag zur direkten Kopplung Fluidextraktion-Kapillarfluidchromatographie, III. Experimentelle Optimierung des Druck- und Temperaturprogramms in der Fluidchromatographie im Hinblick auf die Analyse von Milchprodukten. Mitt Geb Lebensmittelunters Hyg 78, 21-35

Godefroot M, Sandra P, Verzele M (1981) New method for quantitative essential oil analysis. J Chromatogr 203, 325-335

Görner F, Palo V, Bertan M (1968) Veränderungen des Gehaltes der flüchtigen Stoffe während der Joghurtreifung. Milchwissenschaft 23, 94-100

Grigoryeva DN, Golovnya RV, Syomina LA, Vasilyev AV, Samusenko AL (1994) Correlation between sensory and gas chromatographic characteristics of Dutch cheese. In: Trends in Flavour Research. (Maarse H, van der Heij DG, eds) Elsevier, Amsterdam, 283-286 
Grob K, Karrer G, Riekkola ML (1985) On-column injection of large sample volumes using the retention gap technique in capillary gas chromatography. J Chromatogr 334, 129-155

Grosch W (1990) Analyse von Aromastoffen. Chem Unserer Zeit 24 (2), 82-89

Grosch W, Preininger M, Warmke R, Belitz HD (1994) Studies on the flavour of Swiss cheese (Emmentaler). In: Aroma Perception, Formation, Evaluation (Rothe M, Kruse HP, eds) Deutsches Inst Ernährungsforsch, Postdam-Rehbrücke, 425-439

Groux M, Moinas M (1974) La flaveur des fromages. II. Etude comparative de la fraction volatile neutre de divers fromages. Lait 54, 44-52

Guichard E (1994) Study of key flavor compounds in AOC cheese. In: Flair Sens Project (Matforsk Flair Sens Project, Management Team, eds) Ås-Trykk, As, Norway, 87-89

Guichard E, Berdagué JL, Grappin R, Fournier N (1987) Affinage et qualité du Gruyère de Comté. V Influence de l'affinage sur la teneur en composés volatils. Lait $67,319-338$

Guichard H (1995) Contribution au développement de méthodes instrumentales pour l'étude des fractions volatile et azotée soluble dans l'eau de fromages à pâte pressée cuite. Relation avec l'analyse sensorielle. Thèse de doctorat, Univ Bourgogne, France

Guichard H, Guichard E, Langlois D, Issanchou S, Abbott N (1995) GC sniffing analysis: olfactive intensity measurement by two methods. Z Lebensm Unters Forsch 201, 344-350

Henneberg D, Weimann B, Zalfen U (1993) Computer-aided interpretation of mass spectra using databases with spectra and structures. I. Structure searches. Org Mass Spectrom 28, 198-206

Hild J (1979) Quantitative Bestimmung einiger wichtiger Aromakomponenten in Milcherzeugnissen mittels Head-Space-Technik, Milchwissenschaft $34,281-283$

Horwood JF (1989) Headspace analysis of cheese. Aust J Dairy Technol 44, 91-96

Imhof R, Bosset JO (1989) Einfache quantitative photometrische Bestimmung von 'Gesamt'-Carbonylkomponenten in biologischen Medien. Mitt Geb Lebensmittelunters Hyg 88, 409-419

Imhof R, Bosset JO (1991) Comparison of two systems for sample preparation and injection by dynamic headspace GC analysis. I High Resol Chromatogr $14,621-625$
Imhof R, Bosset JO (1994a) The performance of various capillary columns for the analysis of volatile flavor compounds in dairy products by dynamic headspace gas chromatography, J High Resol Chromatogr 17, 25-30

Imhof R, Bosset JO (1994b) Quantitative GC-MS analysis of volatile flavour compounds in pasteurized milk and fermented milk products applying a standard addition method, Lebensm Wiss Technol 27, 265-269

Jackson P, Dent G, Carter D, Schofield DJ, Chalmers JM, Visser T, Vredenbregt M (1993) Investigation of high sensitivity GC-FTIR as an analytical tool for structural identification. J High Resol Chromatogr 16, 515-521

Jain MK, Singhal OP (1969) Chemistry of ghee flavours. II. Variations in carbonylic flavour compounds in ghee made from desi butter. Indian. $J$ Dairy Sci 22, 103-108

Jennings WG, Filsoof M (1977) Comparison of sample preparation techniques for gas chromatographic analysis. J Agric Food Chem 25, 440-445

Jennings WG, Rapp A (1983) Sample Preparation for Gas Chromatographic Analysis (Bertsch W, Jennings WG, Kaiser RE, eds) A Hütig Verlag, Heidelberg, 1-104

Jeon IJ, Thomas EL, Reineccius GA (1978) Production of volatile flavor compounds in ultra-high temperature processed milk during aseptic storage. JAgric Food Chem 26, 1183-1188

Kahlhofer H (1981) Aromakontrolle mit Hilfe der Head Space-Technik. Milchw Berichte 68 , 197-202

Karlsson HOE, Trägårdh G (1996) Application of pervaporation in food processing. Trends Food Sci Technol 7, 78-83

Kasalinsky VF, McDonald JT Jr (1983) GC/FTIR spectra of terpenes. J Chromatogr Sci 21, 193-200

Klein B, Gauch R, Bosset JO (1990) Comparison of four extraction, concentration and injection techniques for volatile compounds analysis by $\mathrm{GC}-\mathrm{MS}$ : an application to the study of the volatile flavour of Swiss Emmentaler cheese. In: Flavour Science and Technology (Bessière Y, Thomas AF, eds) John Wiley and Sons, Chichester, 205-208

Kowalewska J, Zelazowska H, Babuchowski A, Hammond EG, Glatz BA, Ross F (1985) Isolation of aroma-bearing material from Lactobacillus helveticus culture and cheese, J Dairy Sci 68 , 2165-2171

Kubeczka KH (1981) Application of HPLC for the separation of flavour compounds. In: Flavour '81, 
3rd Weurman Symp Proc Int Conf, Munich, April 28-30, 1981 (Schreier P, ed) W de Gruyter, Berlin, 345-359

Lacrampe JL, Dherbomez M, Weber F (1975) Problèmes d'extraction et d'analyse de certains composés aromatiques des produits laitiers. I. Techniques de concentration et d'extraction. Lait 55 , 517-529

Lamparsky D, Klimes I (1981) Cheddar cheese flavour - its formation in the light of new analytical results. In: Flavour '81, 3rd Weurman Symp Proc Int Conf. Munich, April 28-30, 1981 (Schreier P, ed) W de Gruyter, Berlin, 557-577

Laye I, Karleskind D, Morr CV (1995) Dynamic headspace analysis of accelerated storage commercial whey protein concentrate using four different adsorbent traps. Milchwissenschaft 50 , 268-272

Leahy MM, Reineccius GA (1984) Comparison of methods for the isolation of volatile compounds from aqueous model systems. In: Analysis of Volatiles (Schreier P, ed) W de Gruyter, Berlin, $19-48$

Liardon R, Bosset JO, Blanc B (1982) The aroma composition of Swiss Gruyère cheese. I. The alkaline volatile components. Lebensm Wiss Technol $15,143-147$

Libbey LM, Bills DD, Day EA (1963) A technique for the study of lipid-soluble food flavor volatiles. J Food Sci 28, 329-333

Liebich HM, Douglas DR, Bayer E, Zlatkis A (1970) The volatile flavor components of Cheddar cheese. J Chromatogr Sci 8, 355-359

Linssen J, Reitsma H, Cozijnsen J (1995) Static headspace gas chromatography of acetaldehyde in aqueous foods and polythene terephthalate. Z Lebensm Unters Forsch 201, 253-255

Lund ED (1994) Determination of 2-methoxy-3alkylpyrazines in carrot products by gas chromatography/nitrogen-phosphorus detection. $J$ AOAC Int 77, 416-420

Maarse H (1983) Volatile Compounds in Food. Ser 1: Qualitative Data. Ser 2: Quantitative Data. Div Nutrition and Food Research TNO Inst CIVO Analysis TNO, Zeist

Maarse H, Belz R (1981) Isolation, separation and identification of volatile compounds in aroma research. In: Handbuch der Aromaforschung (Rothe M, ed) Akademie Verlag, Berlin, 1-290

MacNamara K, Brunerie P, Squarcia F, Rozenblum A (1995) Investigation of flavour compounds in whiskey spent lees. In: Food Flavors: Generation,
Analysis and Process Influence. Proc 8th Int Flavor Conf, Cos, Greece, 6-8 July 1994 (Charalambous G, ed) Elsevier, Amsterdam, 1753-1766

Maignial L, Pibarot P, Bonetti G, Chaintreau A, Marion JP (1992) Simultaneous distillation-extraction under static vacuum: isolation of volatile compounds at room temperature. J Chromatogr 606 , $87-94$

Majors RE (1995) Sample preparation perspectives. The use of membranes in sample preparation. LC-GC Int 8, 375-380

Manning DJ (1974) Sulphur compounds in relation to Cheddar cheese flavour. J Dairy Res 41, 81-87

Manning DJ, Moore C (1979) Headspace analysis of hard cheeses. J Dairy Res 46, 539-545

Manning DJ, Price JC (1983) Instrumental methods in determining flavour. I Soc Dairy Technol 36, 33-35

Marsili R (1996) Techniques for analyzing food aroma. In: Food Sci Technol Ser/79 (Marsili R, ed) Marcel Dekker Inc, New York and Basel, 1-400

McGugan WA, Howsam SG, Elliott JA, Emmons DB, Reiter B, Sharpe ME (1968) Neutral volatiles in Cheddar cheese made aseptically with and without starter culture. J Dairy Res 35, 237-245

McNeal TP, Hollifield HC (1990) Quantitative multiresidue analyses for volatile organics in water and milk, using a fused silica open-tubular widebore capillary column and automated headspace gas chromatogrography. I Assoc Off Anal Chem $73,328-331$

Mick S, Mick W, Schreier P (1982) The composition of neutral volatile constituents of sour cream butter. Milchwissenschaft 37, 661-665

Miranda-Lopez R, Libbey LM, Watson BT, McDaniel MR (1992) Odor analysis of Pinot Noir wines from grapes of different maturities by a gas chromatography-olfactometry technique (Osme). J Food Sci 57, 985-1019

Mistry BS, Reineccius GA, Jasper BL (1994) Comparison of gas chromatographic detectors for the analysis of volatile sulfur compounds in foods. In: ACS Symp Ser 564. Sulfur Compounds in Foods (Mussinan CJ, Keelan ME, eds) Am Chem Soc, Washington DC, 8-21

Mogl S, Haas J, Knutti R (1995) Bestimmung von VOC in Büroräumen. Analytischer Erfahrungsbericht ibber eine europäische Studie an 56 Bürogebäuden. Mitt Geb Lebensmittelunters Hyg 86 , 657-671 
Moinas M (1973) Arôme volatil de produits laitiers - extraction et identification. Trav Chim Aliment Hyg 64, 59-65

Moinas M, Groux M, Horman I (1973) La flaveur des fromages. L Une méthodologie nouvelle d'isolement de constituants volatils. Application au Roquefort et au Camembert. Lait 53, 601-609

Moio L, Dekimpe J, Etievant P, Addeo F (1993a) Neutral volatile compounds in the raw milks from different species. J Dairy Res 60, 199-213

Moio L, Langlois D, Etievant P, Addeo F (1993b) Powerful odorants in bovine, ovine, caprine and water buffalo milk determined by means of gas chromatography-olfactometry. J Dairy Res 60 , 215-222

Moio L, Etievant P, Langlois D, Dekimpe J, Addeo $F$ (1994) Detection of powerful odorants in heated milk by use of extract dilution sniffing analysis. J Dairy Res 61, 385-394

Molimard P, Spinnler HE (1996) Review: compounds involved in the flavor of surface mould-ripened cheeses: origins and properties. J Dairy Sci 79 . 169-184

Monnet C, Schmitt P, Divies C (1994) Method for assaying volatile compounds by headspace gas chromatography and application to growing starter cultures. J Dairy Sci 77, 1809-1815

Morgan ME (1976) The chemistry of some microbially-induced flavor defects in milk and dairy foods. Biotechnol Bioeng 18, 953-965

Mosandl A (1995) Enantioselective capillary gas chromatography and stable isotope ratio mass spectrometry in the authenticity control of flavors and essential oils. Food Rev Int 11, 597-664

Namba R (1990) Industrial applications of GC/FT-IR. In: Practical Fourier Transform Infrared Spectroscopy (Ferraro JR, Krishnan K, eds) Academic Press, New York, 469-518

Nedjma M, Maujean A (1995) Improved chromatographic analysis of volatile sulfur compounds by the static headspace technique on water-alcohol solutions and brandies with chemiluminescence detection. J Chromatogr A 704, 495-502

Ney KH (1973) Technik der Aromauntersuchung. Gordian 73, 380-387

Ney KH, Wirotama IPG (1978) Untersuchung der Aromabestandteile von Fontina, einem italienischen Käse. Fette Seifen Anstrichm 80, 249-251

Nickerson GB, Likens ST (1966) Gas chromatographic evidence for the occurrence of hop oil components in beer $J$ Chromatogr 21, 1-5
Núñez AJ, Bemelmans JMH (1984) Isolation methods for the volatile components of grapefruit juice. Distillation and solvent extraction methods. Chromatographia 18, 153-158

Nursten HE (1977) The important volatile components of foods. In: Sensory Properties of Foods (Birch GG, Brennan JG, Parker KJ, eds) Appl Sci Publ, London, 151-166

Nursten HE (1979) Why flavour research? How far have we come since 1975 and where now? In: Progress in Flavour Research (Land DG, Nursten HE, eds) Appl Sci Publ, London, 337-355

Nursten HE, Sheen MR (1974) Volatile flavour components of cooked potato. J Sci Food Agric 25, 643-663

O'Hare WT, Nursten HE (1994) Prediction of late gas formation in commercially produced Cheddar cheese by headspace measurements at 8 weeks. In: Trends in Flavour Research. (Maarse H, van der Heij DG, eds) Elsevier, Amsterdam, 151-155

Oria R, Condon S, Sala TF (1987) Headspace profiles sampling and recording method for cheese. Milchwissenschaft 42, 713-716

Paillard N, Pitoulis S, Mattei A (1970) Techniques de préparation et analyse de l'arôme de quelques fruits. Lebensm Wiss Technol 3, 107-114

Parliment TH, Kolor MG, Rizzo DJ (1982) Volatile components of Limburger cheese. J Agric Food Chem 30, 1006-1008

Pearce TC, Gardner JW, Friel S, Bartlett PN, Blair N (1993) An electronic nose for monitoring the flavour of beers. Analyst 118, 371-377

Pesyna GM, Venkataraghavan R, Dayringer HE, McLafferty FW (1976) Probability based matching system using a large collection of reference mass spectra. Anal Chem 48, 1362-1368

Pierce K (1995) Reflections on chirality. Anal Eur April, 31-32

Preininger M, Grosch W (1994) Evaluation of key odorants of the neutral volatiles of Emmentaler cheese by the calculation of odour activity values. Lebensm Wiss Technol 27, 237-244

Preininger M, Rychlik M, Grosch W (1994) Potent odorants of the neutral volatile fraction of Swiss cheese (Emmentaler). In: Trends in Flavour Research. (Maarse H, van der Heij DG, eds) Elsevier, Amsterdam, 267-270

Preininger M. Warmke R, Grosch W (1996) Identification of the character impact flavour compounds of Swiss cheese by sensory studies of models. Z Lebensm Unters Forsch 202, 30-34 
Price JC, Manning DJ (1983) A new technique for the headspace analysis of hard cheese. $J$ Dairy Res $50,381-385$

Reineccius GA, Anandaraman S (1984) Analysis of volatile flavors. In: Food Constituents and Food Residues (Lawrence JF, ed) M Dekker, Basel, 195-293

Rothe M, Thomas B (1963) Aromastoffe des Brotes. Z Lebensm Unters Forsch 119, 302-310

Sanz J, de Frutos M, Martinez-Castro I (1992) Design of a mixed-phase capillary column for the gas chromatographic separation of the volatile components of cheese. Chromatographia 33,213-217

Sävenhed R, Borén H, Grimwall A (1985) Stripping analysis and chromatographic sniffing for the source identification of odorous compounds in drinking water. J Chromatogr 328, 219-231

Schieberle P, Grosch W (1987) Quantitative analysis of aroma compounds in wheat and rye bread crusts using a stable isotope dilution assay. J Agric Food Chem 35, 252-257

Schreier P, Idstein H (1985) High-resolution gas chromatography - Fourier transform infrared spectroscopy in flavour analysis: limits and perspectives. Z Lebensm Unters Forsch 180, 183-188

Schwartz DP, Shamey J, Brewington CR, Parks OW (1968) Methods for the isolation and characterization of constituents of natural products. X. New and improved methods for the analysis of carbonyl 2,4-dinitrophenylhydrazones and 2,4-dinitrophenylosazones. Microchem J 13,407-417

Sedlácková B, Kakalíková L, Matisovà E, Farkas P, Dobos A (1995) Analysis of volatile compounds in various wines. Anal Methods Instrum 2, 106-108

Shiratsuchi H, Shimoda M, Imayoshi K, Noda K, Osajima Y (1994) Volatile flavor compounds in spray-dried skim milk powder. J Agric Food Chem 42, 984-988

Sloot D, Harkes PD (1975) Volatile trace components in Gouda cheese. J Agric Food Chem 23, 356-357

Stark W, Urbach G, Hamilton JS (1976) Volatile compounds in butter oil. V. The quantitative estimation of phenol, $o$-methoxyphenol, $m$ - and $p$-cresol, indole and skatole by cold-finger molecular distillation. J Dairy Res 43, 479-489

Stark W, Urbach G, Cook LJ, Ashes JR (1978) The effect of diet on the $\gamma$ - and $\delta$-lactone and methyl ketone potentials of caprine butterfat. J Dairy Res $45,209-221$

Steely JS (1994) Chemiluminescence detection of sulfur compounds in cooked milk. In: ACS Symp Ser
564. Sulfur Compounds in Foods (Mussinan CJ, Keelan ME, eds) Am Chem Soc, Washington DC, 22-35

Sugisawa H, Chen C, Nabeta K (1984) Simultaneous distillation adsorption and its application. In: Analysis of Volatiles (Schreier P, ed) W de Gruyter, Berlin, 357-369

Takacs F Jr (1989) Solid-phase extraction of stale flavor components from ultra-high-temperature processed milk. MS thesis, Kansas State Univ, Manhattan, KS

Tan T, Lucas Q, Moy L, Gardner J, Bartlett P (1995) The electronic nose - a new instrument for sensing vapours. LC GC Int 8, 218-225

Teranishi R, Issenberg P, Hornstein I, Wick EL (1971) Flavor Research, Principles and Techniques. M Dekker Inc, New York

Traitler H, Horman I (1990) GC-MS; Simultaneous quantification and identification by column effluent splitting. J High Resol Chromatogr 13. 197-198

Tuan HPT, Janssen HGM, Cramers CA, Kuiper-van Loo EM, Vlap H (1995) Evaluation of the performance of various universal and selective detectors for sulfur determination in natural gas. $I$ High Resol Chromatogr 18, 333-342

Ulberth F (1991) Headspace gas chromatographic estimation of some yogurt volatiles. J Assoc Off Anal Chem 74, 630-634

Ulberth F, Roubicek D (1995) Monitoring of oxidative deterioration of milk powder by headspace gas chromatogrography. Int Dairy J 5, 523-531

Ullrich F, Grosch W (1987) Identification of the most intense volatile flavour compounds formed during autoxidation of linoleic acid. Z Lebensm Unters Forsch 184, 277-282

Urbach G (1982) The effect of different feeds on the lactone and methyl ketone precursors of milk fat a review. Lebensm Wiss Technol 15, 62-67

Urbach G (1987) Dynamic headspace gas chromatography of volatile compounds in milk. J Chromatogr 404, 163-174

Urbach G (1996) The chemical and biochemical basis of cheese and milk aroma. In: Microbiology and Biochemistry of Cheese and Fermented Milk (Law BA, ed) Blackie Acad \& Prof; imprint of Chapman \& Hall, London, 253-298

Urbach G, Stark W, Forss DA (1972) Volatile compounds in butter oil. II. Flavour and flavour thresholds of lactones, fatty acids, phenols, indole and 
skatole in deodorized synthetic butter. J Dairy Res $39,35-47$

Vámos-Vigyázó L, Kiss-Kutz N (1974) Estimation of volatile acids in Emmental cheese by gas-liquid chromatography. Acta Aliment 3, 309-325

Vandeweghe P, Reineccius GA (1990) Comparison of flavor isolation techniques applied to Cheddar cheese. J Agric Food Chem 38, 1549-1552

Varmuza K, Werther W, Lohninger H (1989) Anwendung chemometrischer Methoden zur Untersuchung von Massenspektren-Struktur-Beziehungen. In: Software-Entwicklung in der Chemie 3 (Gauglitz G, ed) Springer Verlag, Berlin, 267-278

Vidal-Aragón MC, Sabio E, González J, Mas M (1994) Contribution to the study of the volatile compounds in goat milk cheeses from Extremadura: effect of the season of manufacture. Alimentaria 31 (258), 25-29

Wadhwa B, Bindal MP, Jain MK (1979) Isolation, fractionation and characterization of lactonic components of cow ghee. Milchwissenschaft 34, 481-483

Westendorf RG (1985) An instrument for thermal desorption of adsorbent traps. Am Lab December, $72-76$

Weurman C (1969) Isolation and concentration of volatiles in food odor research. J Agric Food Chem $17,370-384$
Wijesundera C, Urbach G (1993) Flavour of Cheddar cheese. Final Rep, Dairy Res Dev Corp, Project Cst66, CSIRO Div Food Science and Technology, Melbourne Laboratory, Highett Vic, Australia

Wong NP, Parks OW (1968) Simple technique for extracting flavor compounds from fatty foods. J Dairy Sci 51, 1768-1769

Wood AF, Aston JW, Douglas GK (1994) A coldtrap method for the collection and determination of headspace compounds from cheese. Aust J Dairy Technol 49, 42-47

Woolley C, Mani V (1994) Schnelle und einfache Bestimmung von Aromastoffen mit Festphasenmikroextraktion und Kapillar GC. Supelco Reporter 13 (4), 9-10

Wyllie SG, Leach DN, Wang Y, Shewfelt RL (1994) Sulfur volatiles in Cucumis melo cv Makdimon (muskmelon) aroma. In: ACS Symp Ser 564. Sulfur Compounds in Foods (Mussinan CJ, Keelan ME, eds) Am Chem Soc, Washington DC, 36-48

Xanthopoulos V, Picque D, Bassit N, Boquien CY, Corrieu G (1994) Methods for the determination of aroma compounds in dairy products: a comparative study. J Dairy Res 61, 289-297

Yang WT, Min DB (1994) Dynamic headspace analyses of volatile compounds of Cheddar and Swiss cheese during ripening. J Food Sci 59, 1309-1312

Zannoni M (1995) Preliminary results of employ of an artificial nose for the evaluation of cheese. Sci Tec Latt-Casearia 46, 277-289 